Historic, Archive Document

Do not assume content reflects current scientific knowledge, policies, or practices. 



\section{Old Colony Nurseries INCORPORATED}

\section{Plymouth, Mass.}

\section{Whe $1840-1914$}

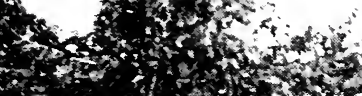

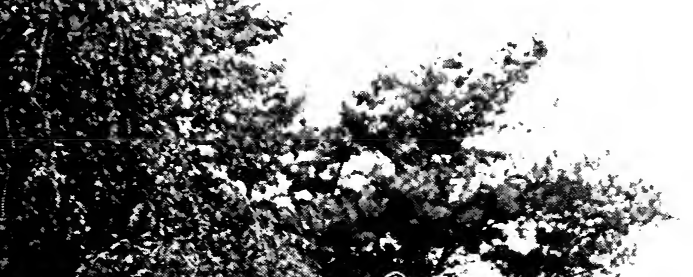

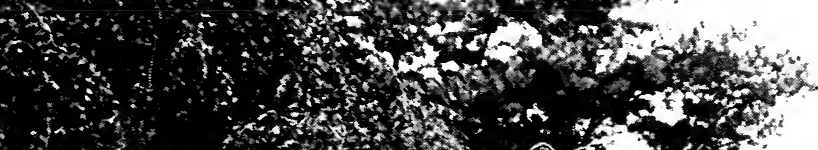

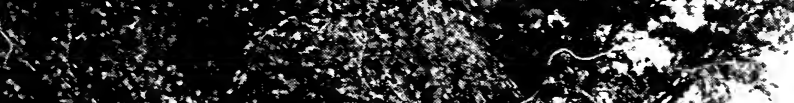

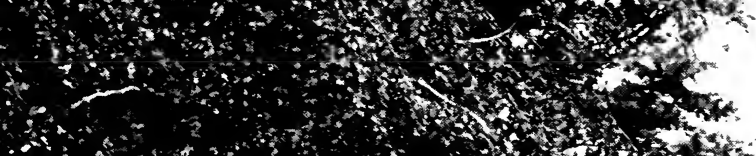

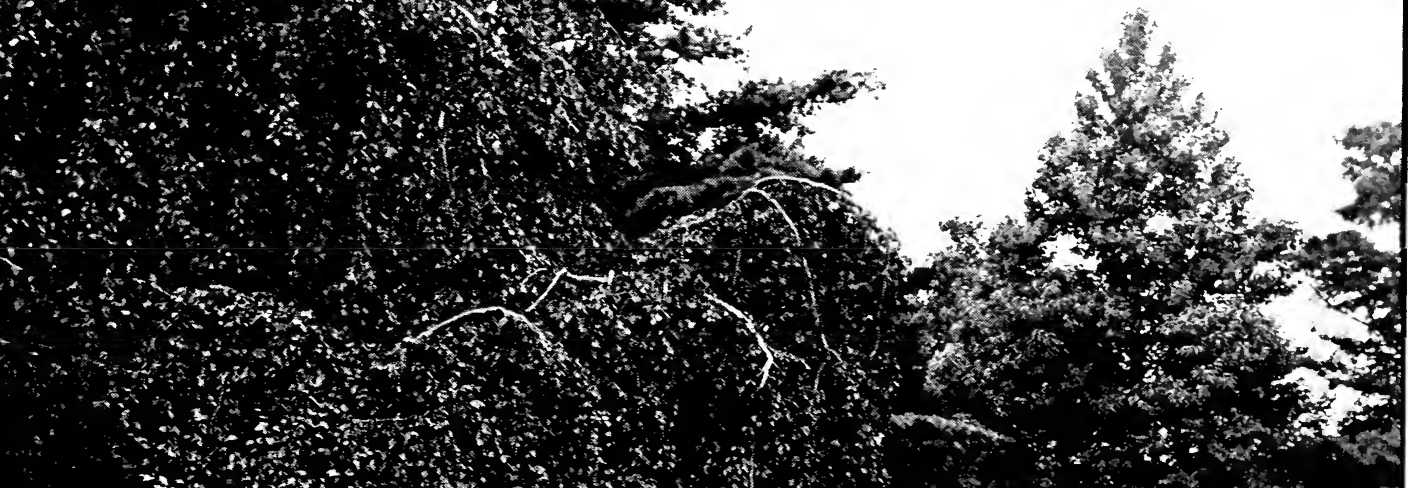

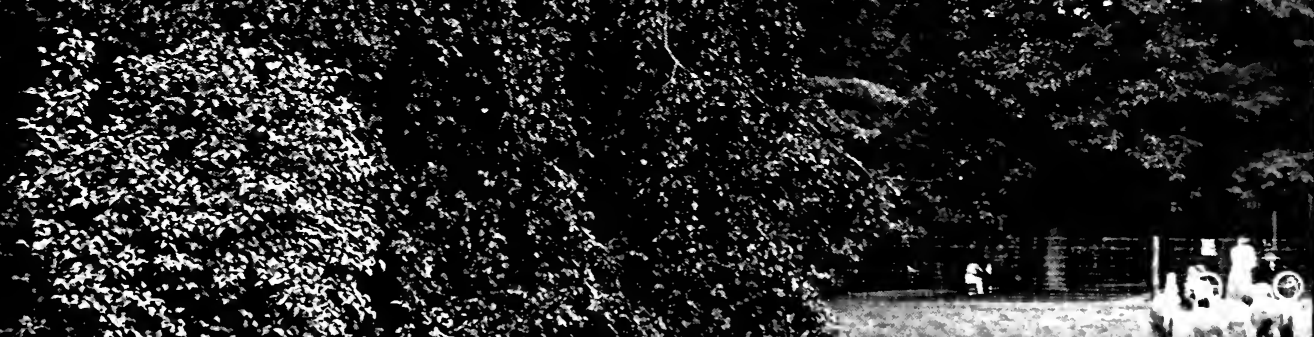

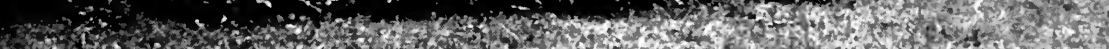

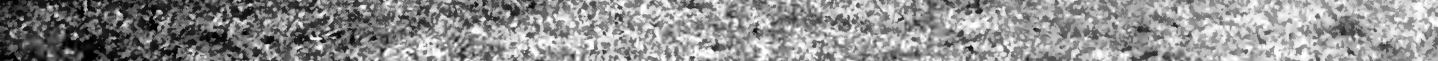

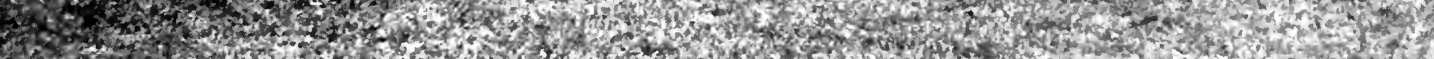

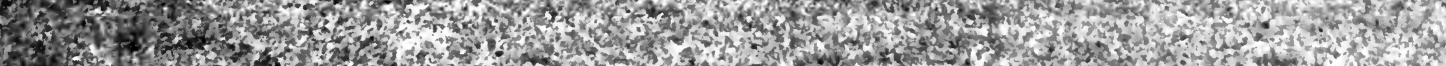

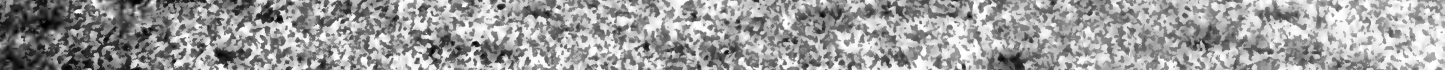

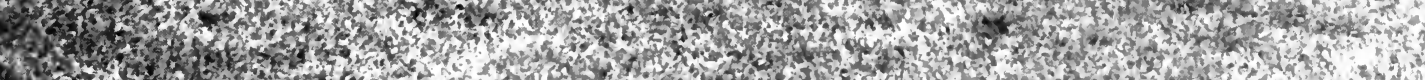

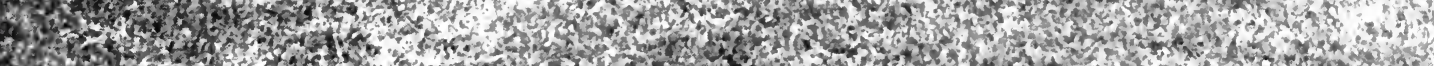
W. merto 


\section{THESE POINTS WILL HELP YOU IN MAKING OUT YOUR ORDER ALSO HELP US IN FILLING IT}

\section{ORDERS}

Please use the order sheet and fill out all the blanks. Write your name and shipping address (also post-office address, if different) as clearly as possible. Say whether you will have the trees, shrubs or plants sent by express or freight.

Orders are filled in order received. If stock is wanted for a specified date, we will endeavor to meet the date, provided the order is received sufficiently in advance.

\section{REMITTANCES}

may be made by personal check, Boston or New York draft, post-office or express money order. Stamps may be sent for purchases not exceeding $\$$ I.

\section{TERMS}

Cash with order or satisfactory references, except where parties are known.

\section{DELIVERY}

We do not prepay either express or freight charges, but all packages are delivered free to the railroad or express company. All plants are at the risk of the purchaser after they are delivered to the public carrier. Notify us at once of any delay in receipt of stock or error in filling order. No complaints are considered unless made within ten days of receipt of stock.

\section{PACKING}

is charged at the actual cost of the case or bale. This varies from ro cts. to $\$ 3$ for cases, and from $\mathrm{I}_{5} \mathrm{cts}$. to $\$ \mathrm{I} .50$ for bales.

\section{GUARANTEE}

We take the greatest pains to have every plant marked true to name. Any plant incorrectly marked will be promptly replaced or money returned. We do not guarantee any more than the original cost of the plant. At the prices quoted in this catalogue we cannot guarantee plants to live. We send out young, thrifty plants, which should live if properly planted and cared for.

\section{SPECIAL PRICES}

From the foilowing list you may order five at the ten rate, fifty at the hundred rate. Special quotations will be given for plants in quantity and to the trade.

\section{OLD COLONY NURSERIES Inc.} Plymouth, Mass. 


\section{BY WAY OF INTRODUCING THE OLD COLONY NURSERIES Inc.}

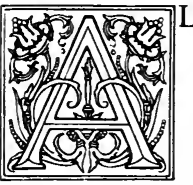

LMOST three generations ago a young man was graduated from Harvard College -in I 839, to be exact-and the following year established himself at his home in Plymouth, Massachusetts, and began to grow gardentruck and fruits. Mr. Benjamin Marston Watson was an ambitious gardener, and in a year or two he found that truck-gardening was not large enough for his business plans, so he decided to expand by starting a nursery.

In those days all fruit stocks were imported from England or the Continent; but Mr. Watson believed he could propagate his own stocks, and soon he had a supply that equaled, if not excelled, those that were purchased abroad. After a time he wished to plant ornamental trees around his own place and, for this purpose imported Norway spruce, Scotch larch, Scotch pine, Austrian pine, etc., and many deciduous trees. He also propagated trees until his requirements were met and a liberal supply provided for the nursery. These first-planted trees are now stately specimens on these grounds.

In a short time he established a fair trade, particularly in the southern states. The difficulties of I86I to I 865 interrupted this trade, but when they were settled the business began to grow again. About $\mathrm{I} 88 \mathrm{o}$, when large estates were being developed, our nurseries were ready to fill big or little orders for big or little American trees and plants.

Careful observation told Mr. Watson that there was a demand for native trees and shrubs, and a variety of American trees and shrubs were planted. It is a sad fact that our native plants have been so much neglected. They are fully as beautiful in foliage and flower, they thrive better and are far more appropriate for American gardens than many imported sorts. We have given particular attention to the various plants which are natives of North America, and the species and varieties here listed have been selected as typifying those best suited to cultivation in various parts of the country.

The light, sandy loam of Cape Cod makes a splendid soil in which to grow little trees, and particularly so when peat, manure and wood-ashes have been added. This light loam does not force the tops like heavier soils, but, in connection with our methods of frequent transplanting, it develops a fibrous root-system which means almost assured success when the trees are set in your orchard or grounds. The porous nature of the soil permits the moisture to dry out quickly in the spring, which facilitates early shipments. Our climate is sufficiently severe to give vigor and hardiness to our stock, and the easterly winds which blow from the Atlantic Ocean retard the unfolding of the foliage, thus giving us a long shipping season. Cellars are little used except for storing young and tender plants. We ship direct from the ground, pack promptly, and use plenty of moss.

Since the very beginning of the business the proprietors have been interested in propagating and introducing new plants, but none have been sent out from the Old Colony Nurseries that have been lacking in merit and value. One of the notable successes that came from our place is Hall's Japanese Honeysuckle, which was sent from Japan to Mr. Watson by Dr. Hall. For the past fifteen years the management of the Old Colony nurseries has been carried on by Mr. Watson's sons, Thomas R. and Edward W., who have increased the plantations and varieties of deciduous trees, shrubs, evergreens, fruits and perennials. The business was incorporated in I9I3.

Our nurseries are always open, and we shall be pleased to have our friends and customers come to Plymouth and see the grounds, the older planting and some of the places of historical interest here. Superb specimens of Tulip trees, Magnolia acuminata, Silver Bell and Southern Cypress are to be seen-trees which were planted sixty years ago by Mr. Watson. Today they are large, healthy trees. Other equally handsome American and European trees are to be found here.

Copyright, I9I4, by Old Colony Nurseries Inc. 


\section{Evergreen Trees}

ARBORVIT E, American. Thuya occidentalis. A native, rapid-growing, pyramidal evergreen; foliage bright green, flat and fern-like. One of the hardiest trees and does well in a great variety of soils. Used for hedge purposes. 3 to $4 \mathrm{ft}$. $50 \mathrm{cts}$. each, $\$ 4$ for $10, \$ 35$ per Ioo; 2 to $3 \mathrm{ft}$. $35 \mathrm{cts}$. each, $\$ 3$ for Io, $\$ 20$ per IOO.

Douglas' Golden. $T$. occidentalis aurea. Broad, bushy form; golden foliage. I 8 to 24 in. $75 \mathrm{c}$. ea., $\$ 6$ for Io.

Siberian. T. Wareana. Very hardy; with heavy, bluish green foliage. I 8 to 24 in. 75 cts. each, $\$ 6$ for 10.

FIR, Balsam. Abies balsamea. A slender, pyramidal tree; very hardy; grows rapidly; foliage a bright green. 2 to $3 \mathrm{ft}$. $50 \mathrm{cts}$. each, $\$ 4$ for Io.

White or Silver. A.concolor. One of the handsomest Firs. Grows very tall, is exceedingly hardy, of graceful habit, with broad foliage, blue on upper surface, silver beneath. 2 to $3 \mathrm{ft} . \$ 2$ each.

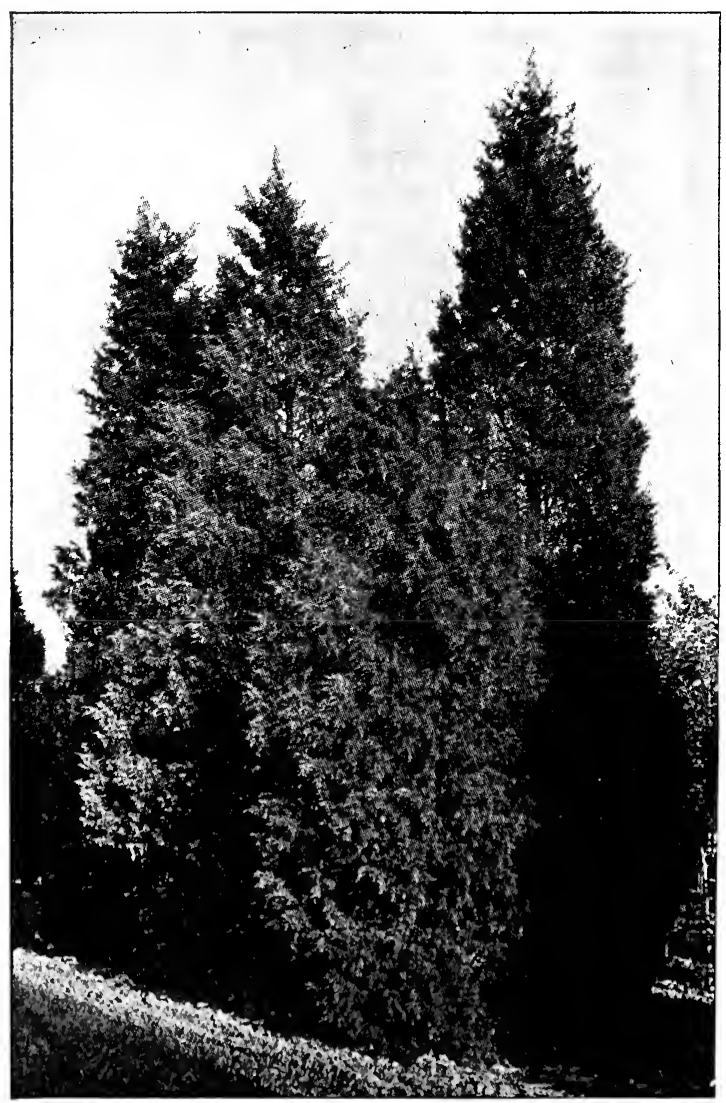

Red Cedars
Fir, Douglas. Pseudotsuga Douglasii. Large; conical form, branches spreading, horizontal; foliage soft. An excellent tree. 4 to $5 \mathrm{ft}$., $\$ 2$ each, 3 to $4 \mathrm{ft}$. $\$ \mathrm{I} .50$ each.

HEMLOCK. Tsuga canadensis. A distinctive native tree, tall, graceful, dense; delicate, dark, glossy green leaves. Good specimen tree, excellent for lawns and hedges. 18 to $24 \mathrm{in}$. 75 cts. each, $\$ 6$ for Io; 24 to 30 in. $90 \mathrm{cts}$. each, $\$ 8.5^{\circ}$ for Io.

JUNIPER, Creeping. Juniperus communis. A dwarf conifer, with broadly spreading branches. Foliage grayish green underneath but much lighter above; very thick. I 5 to 8 in. diam. $75 \mathrm{cts}$. each.

Douglas' Golden. J. communis, aurea. A variety of the Creeping Juniper, with bronze and gold foliage. I 2 to I 5 in. diam. 75 cts. each, $\$ 6$ for Io.

Dahurica. An upright Juniper, quite like the Irish but of lighter color, and supposed to be more enduring. 5 to $6 \mathrm{ft}$. $\$ 2$ each, 3 to $4 \mathrm{ft}$. $\$$ I each.

Irish. J. hibernica. A distinctly beautiful variety; erect, dense, column-like in form; foliage dark green with a bluish tinge. $4 \mathrm{ft}$. $\$ \mathrm{I}$ each; $3 \mathrm{ft} .75 \mathrm{cts}$. each.

Red Cedar. J. virginiana. One of our best native trees, varying much in habit and color; usually tall, spire-like and compact. Perfectly hardy and vigorous, thrifty growers. Fine hedge plant. 2 to $3 \mathrm{ft}$. 75 cts. each.

PINE, Austrian or Black. Pinus austriaca. A robust, massive, hardy tree, with spreading branches and long, stiff, dark green needles; of rapid growth. Valuable for windbreaks and shelter-belts. 2 to $3 \mathrm{ft}$. \$I each.

Dwarf. P. mugho. The best dwarf Pine; of spreading habit, with short, dark green needles. I 5 to 18 in. \$I.25, each, 8 to 12 in. $50 \mathrm{cts}$. each, $\$ 4$ for $\mathrm{ro}$.

Jack. P. Banksiana. Excellent for poor, dry soils; rapid grower and stands exposure to winds well. 4 to $5 \mathrm{ft}$. 75 cts. each, $\$ 6$ for ro. 
EVERGREENS, continued

Pine, Scotch. Pinus sylvestris. Thick, broad and pyramidal in form; 50 to 80 feet high; growth is luxuriant; foliage silvery green; shoots stout and erect. 2 to 3 feet $50 \mathrm{cts}$., $\$ 4$ for IO.

White. P. Strobus. Without doubt the best evergreen for general planting, and the most ornamental of the native Pines, attaining a towering height; foliage light, delicate green; growth is fast, regular and even. 3 to $4 \mathrm{ft}$. $75 \mathrm{cts}$. each, $\$ 6$ for Io, \$50 per IOo; 2 to $3 \mathrm{ft}$. $50 \mathrm{cts}$. each, $\$_{4}$ for Io, $\$ 30$ per IOo.

RETINOSPORA ( J a pa n e se Cedar). Retinospora pisifera. Foliage bright green; pendulous branches; of graceful habit. 2 to $3 \mathrm{ft}$. \$I.50 each.

Pisifera aurea. Same as above, except the foliage is rich golden yellow. 2 to $3 \mathrm{ft}$. \$I.50 each.

Plumosa. Foliage bright green. Sheared, 2 to $3 \mathrm{ft}$., $\$ 1.25$ each.

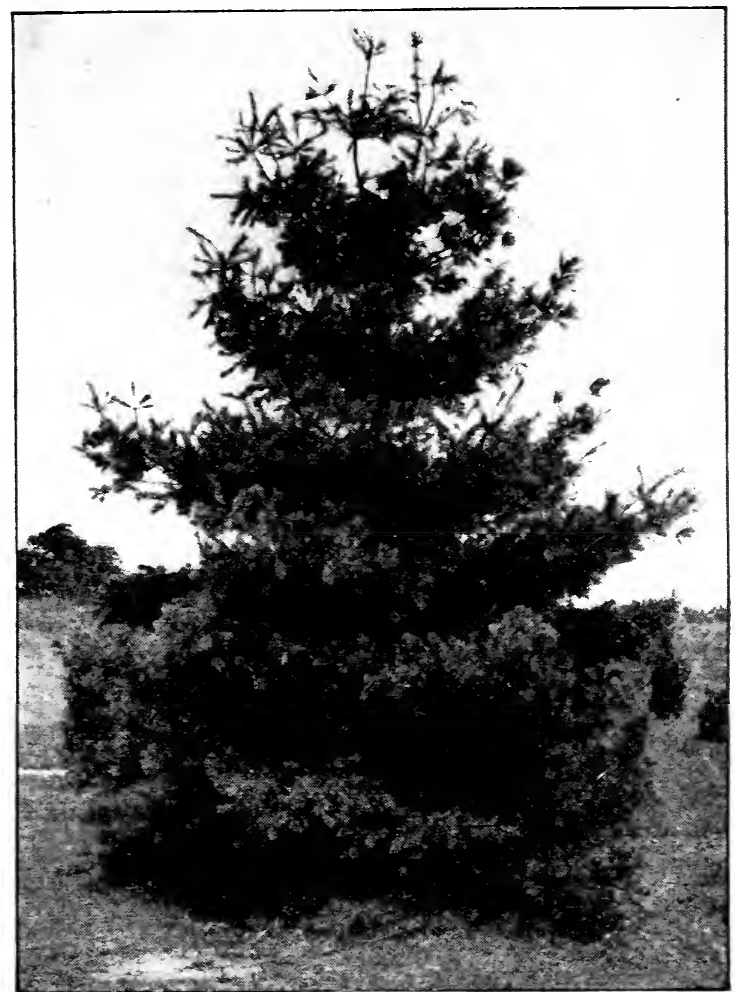

White Pine
Plumosa aurea. Very popular. Its habit is erect and compact; foliage golden. Sheared, 2 to $3 \mathrm{ft}$., Si.25 each; I 8 to 24 in. 75 cts. each. Unsheared, 3 to $4 \mathrm{ft}$., \$1.50 each.

Squarrosa. Silvery foliage. One of the best of the group. Sheared, 2 to $3 \mathrm{ft}$., \$I.5O each.

SPRUCE, White. Picea alba. American tree of dainty appearance, hardy and thrifty, full of little branches that make the tree thick and wind-proof from the ground up. 18 to 24 in. $50 \mathrm{cts}$. each, $\$_{4}$ for Io.

Norway. $P$. excelsa. Splendid, distinguished tree; is a vigorous, rapid grower, attaining large size; spreading, drooping branches and dark green needles. 3 to $4 \mathrm{ft}$. $75 \mathrm{cts}$. each, $\$ 6$ for Io; 2 to $3 \mathrm{ft}$. $50 \mathrm{cts}$. each, $\$ 4$ for Io.

Black. P. nigra. A fine, native tree, compact growth, smooth, blackish bark and bluish leaves; hardy. $6 \mathrm{ft}$. $\$ 2$ each; 2 to $3 \mathrm{ft}$. $75 \mathrm{c}$. each, $\$ 6$ for Io.

Colorado Blue. $P$. pungens glauca. In form and habit similar ta the type, but with glaucous blue foliage; thrives in any soil. $=3$ to $4 \mathrm{ft}$. $\$ 5$ each;' 2 to $3 \mathrm{ft}$. $\$ 3$ each.
Spruce, Koster's Blue. P. pungens glauca Kosteriana. A magnificent Spruce; stiff and formal in outline, with a silvery blue foliage much brighter than the other varieties. Generally considered one of the finest Spruces for ornamental planting. $3 \mathrm{ft}$. St each; 24 to 30 in. \$2. each.

Koster's Blue, Compact. $P$. pungens glauca Kosteriana compacta. Similar to above, except that the foliage is more closely set on the thick-growing branches. I 2 to $\mathrm{I} 8 \mathrm{in}$. \$1.5O.

Green. P. pungens. The type of this species, with green leaves. 4 to $5 \mathrm{ft}$. $\$ 3.50$ each; 3 to $4 \mathrm{ft}$. \$2 each; 2 to $3 \mathrm{ft}$. \$I.5O each.

YEW, JAPANESE. Taxus cuspidata. It is very hardy, small, long-lived attractive evergreen of spreading habit, light green leaves and, in late summer, bearing a bright red, berrylike fruit which shines brilliantly against the foliage; splendid for ornamental uses. 30 in. $\$ 2.50$ each; I 8 to 24 in. \$1.75 each.

Cuspidata brevifolia. A form of above, with short, dark green leaves. I 8 in. Si.5o each. 


\section{Evergreen Shrubs}

ANDROMEDA floribunda. A native Andromeda, blooming in early April, with abundant white flowers in dense racemes. The buds set in summer and the plant is picturesque in winter. One of our best ornamental shrubs. I 2 to I 5 in. \$I each.

Japonica. Somewhat like the preceding, but with better foliage and finer flowers. Not so hardy, and should be planted in a sheltered location. I 2 to I 8 in. \$I each.

BEARBERRY. Arctostaphylos uva-ursi. A hardy, trailing evergreen vine. Valuable for covering rocky slopes and sandy banks; foliage small. Flowers white, tinged with red. Small plants 25 cts. each, $\$ 2.25$ for IO, \$I 5 per IOO.

BOX. Buxus sempervirens. Particularly attractive for decorative purposes and formal gardens. Deep green, glossy foliage. Pyramids, $2 \mathrm{1} / 2 \mathrm{ft}$. $\$ \mathrm{I} .50$ each; $3 \mathrm{ft}$. \$2 each. Standards, 2-ft. stem, I-ft. crown, \$2 each. Bushes, untrimmed, I ft. $35 \mathrm{cts}$. each, $\$ 3$ for IO, $\$ 25$ per Ioo.
Box, Dwarf. B. sempervirens suffruticosa. Excellent for edging. Similar to above, but with much smaller leaves, and dwarf. 4 to 6 in. I 5 cts. each, $\$ \mathrm{I} .25$ for IO, \$IO per Ioo.

EUONYMUS, Creeping. See Vines, page 17 .

LAUREL, American or Mountain. Kalmia latifolia. A splendid, native evergreen shrub, with thick, showy clusters of pink or almost white flowers. With ball, 2 to $2 \mathrm{r} / 2 \mathrm{ft}$., $\$$ I.75 each; with ball, I 2 to $\mathrm{I} 5$ in., 50 cts. each, $\$ 4.50$ for Io.

LEUCOTHOE Catesbæi. A beautiful evergreen shrub from the Allegheny region. During the growing season the foliage is green, but takes on bronze-color in autumn and winter. Plant in a shady place in soil made largely of humus. I 2 to I 5 in. $75 \mathrm{cts}$. each.

RHODODENDRONS. These evergreen shrubs produce magnificent flowers; they require a fine soil and do best in a slightly shaded situation.

English Hybrids in variety, I 8 to 30 in., $\$ 2$ each, \$I 7.50 for Io.

These Anthony Waterer $\mathbf{R h o d o d e n -}$ drons are the best plants obtainable for New England:

Alba elegans. White.

Alba grandiflora. White.

Atrosanguinea. Red.

Caractacus. Rich purplish crimson.

Charles Dickens. Dark scarlet.

Delicatissima. Blush.

Everestianum. Lilac.

James Bateman. Rosy scarlet.

Kettledrum. Crimson.

Lady Armstrong. Pale rose.

Rhododendron Cataw biense Seedlings, mixed colors. 2 ft. $\$ 1.50, \$ 10$ for 10 .

Rhododendron maximum in carload lots. Prices will be quoted on application.

Rhododendrons are magnificent native Shrubs 


\section{Deciduous Trees}

ALDER. Alnus glutinosa. Rapid-growing, vigorous tree, attaining large size and graceful form. Has handsome foliage, rich green above, pale below. Good for damp places. 8 to io $\mathrm{ft}$. 50 cts. each, $\$ 3.5^{\circ}$ for Io.

APPLES, Flowering Crab. See Shrubs, page 9.

BEECH, European. Fagus sylvatica. The Beech is noted for rich, glossy foliage and elegant habit. This particular variety reaches 60 to 80 feet in height. 5 to $6 \mathrm{ft}$. $75 \mathrm{cts}$. each, $\$ 6$ for 10 .

Fern-leaved. $F$. sylvatica asplenifolia. A sport of the above, of moderate size and symmetrical growth, with finely cut leaves. An interesting tree. 4 to $6 \mathrm{ft}$. $\$ 2$ each.

Weeping. $F$. sylvatica pendula. A picturesque tree of large size and exceeding grace and beauty; magnificent in later years. Io to $12 \mathrm{ft}$. $\$ 3$ each; 4 to $5 \mathrm{ft}$. \$I.50 each.

Weeping Purple. F. sylvatica pendula purpurea. A strictly pendulous variety, with rich purple foliage. 3 to $4 \mathrm{ft}$. $\$ 2$ each.

Rivers' Smooth-leaved Purple. $F$. sulvatica purpurea Riversii. Of compact, symmetrical habit. Foliage red in early spring, changing to a dark purple in summer. The best of all the purple-leaved trees. 8 to $9 \mathrm{ft}$. $\$ 2$ each; 6 to $8 \mathrm{ft}$. $\$ \mathrm{I} .50$ each.

Purple-leaved. $F$. sylvatica purpurea. Good stock of seedlings. Not so dark in color of foliage as Riversii. 8 to $9 \mathrm{ft} .75 \mathrm{cts}$. each, $\$ 5$ for $\mathrm{IO}$.

BIRCH, European White. Betula alba. A tall and elegant roadside tree, with exquisite, silvery bark; erect in youth but later attaining a graceful, drooping habit; a very rapid grower; branches are slender and leaves are small, delicately cut and smooth. 4 to $5 \mathrm{ft}$. $50 \mathrm{cts}$. each, $\$ 4$ for Io; 2 to $3 \mathrm{ft} .25 \mathrm{cts}$. each, $\$ 2.25$ for IO.

Cut-leaved Weeping. $B$. alba laciniata. A splendid tree for lawn planting. Of tall, slender, vigorous growth, with very white bark. Io to I2 ft. \$I each.

River or Red. B. nigra. A native species of fine habit and medium growth, with splendid foliage and reddish brown, fluffy bark. 4 to $5 \mathrm{ft}$. $50 \mathrm{cts}$. each, $\$ 4$ for IO.
Birch, Paper. B. papyrifera. Like the common Birch, except that the bark is a brilliant white, and the leaves large and handsome. 3 to $4 \mathrm{ft}$. 25 cts. each, $\$ 2.25$ for Io.

American White or Gray. B. populifolia. An American tree of rapid growth, with triangular, pointed, glossy foliage. 3 to $4 \mathrm{ft}$. 25 cts. each, $\$ 2.25$ for IO.

BLACK WALNUT. Juglans nigra. A stately tree, attaining great size; handsome foliage and dark, furrowed bark; thrives well on good soils. 6 to $8 \mathrm{ft} .75 \mathrm{cts}$. each.

BUTTERNUT, or WHITE WALNUT. $J$. cinerea. A lofty, spreading tree, with grayish bark; bears large, oblong, oily, rough nuts. 4 to $5 \mathrm{ft}$. $75 \mathrm{cts}$. each.

CERCIDIPHYLLUM japonicum. A rare tree from Japan. The growth is upright and very symmetrical; leaves small and heart-shaped. 6 to $8 \mathrm{ft}$. $\$ 1.25$ each.

CHESTNUT, American. Castanea americana. A majestic and very beautiful tree. The branches are spreading and its leaves are broad; the fruit is excellent. $8 \mathrm{ft}$., $75 \mathrm{cts}$. each.

CATALPA. Catalpa speciosa. Good for ornamental and recommended for forest planting. Has large, yellowish green leaves, with showy, fragrant blossoms in July. 8 to Io ft. $75 \mathrm{cts}$. each, $\$ 6$ for 10; 6 to $8 \mathrm{ft}$. $50 \mathrm{cts}$. each, $\$ 4$ for Io.

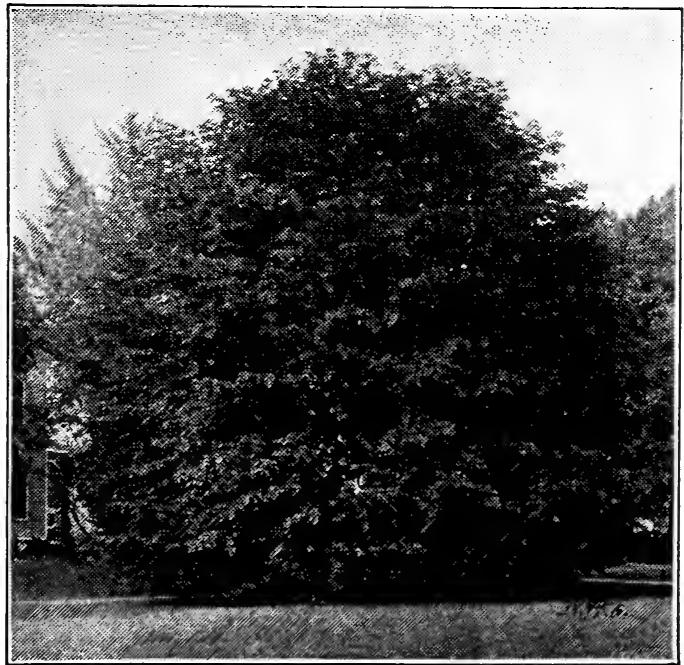

Purple Beech 


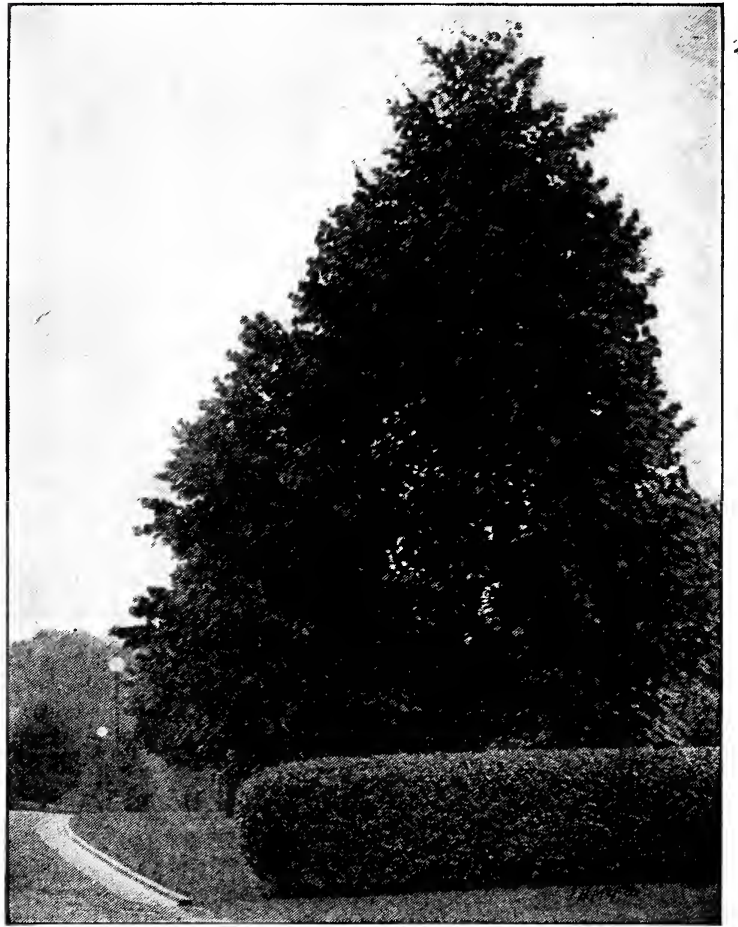

American Linden (see page 7)

DECIDUOUS TREES, Continued

CHERRY. Prunus avium alba $f$. pl. Flowers very double and pure white. 3 to $4 \mathrm{ft}$. $50 \mathrm{cts}$. each.

pendula. A small, weeping tree, covered with a mass of pinkish flowers in early April; very beautiful. \$I.50 each.

Pseudo-Cerasus. A small tree, with spreading branches and double, rosecolored flowers; glossy, grayish green leaves. 4 to $6 \mathrm{ft}$. $50 \mathrm{cts}$. each.

subhirtella. A small tree of upright habit, supposed to be the type from which $P$. pendula was derived. Covered in early April with pinkish white flowers. $6 \mathrm{ft}$. \$3 each.

European Bird. P. padus. A rapidgrowing tree, with large, glossy foliage; long racemes of white, fragrant flowers in May, and currant-like fruit-clusters. 4 to $6 \mathrm{ft}$. $35 \mathrm{cts}$. each.

CYPRESS. Taxodium distichum. A stately tree, with small, feathery, light green foliage. 6 to $8 \mathrm{ft} .75 \mathrm{cts}$. ea.

DOGWOOD, Flowering. See Shrubs, page II.

ELM, American White. Ulmus americana. A grand tree, native of our American forests; lofty, noble and spreading with branches drooping; exceedingly picturesque. 8 to Io $\mathrm{ft}$. $\$$ I each, 6 to $8 \mathrm{ft}$. $50 \mathrm{cts}$. each, $\$ 4$ for Io.
GOLDEN CHAIN. Laburnum vulgare. A small but beautiful tree, covered with long racemes of yellow flowers. In the North should be planted in a sheltered place. 5 to $6 \mathrm{ft}$. $75 \mathrm{cts}$. each.

HAWTHORN, Common or English. Cratcegus oxyacantha. A beautiful, low tree or bush of dense growth; foliage glossy green; branches spreading, covered with short, stiff spines; showy, single white flowers and red fruit. 3 to $4 \mathrm{ft}$. 25 cts. each, $\$ 2.25$ for Io.

Double Pink. C. oxyacantha, fl. pl. rosea. Like the above; double pink flowers. 5 to $6 \mathrm{ft}$. 5oc. each.

Paul's Scarlet. C. oxyacantha Paulii flore pleno. Flowers bright scarlet; double and very showy. 5 to $6 \mathrm{ft}$. 50 cts. each.

Double White. C. oxyacantha alba flore pleno. This variety has double white flowers. Fine when planted so as to contrast with other Hawthorns. 5 to $6 \mathrm{ft}$. 5oc. ea.

Mollis. A native American Thorn, with large, showy flowers, and fine fruit in autumn. 3 to $4 \mathrm{ft}$. $50 \mathrm{cts}$. ea.

HORSE-CHESTNUT, European or Common. Asculus hippocastanum. Tree of good habit, globe-like in form; large, five-parted foliage. Has erect spikes of white flowers in May. 8 to Io $\mathrm{ft}$., I I $/ 2$ to $2 \mathrm{in}$. caliper, $\$ \mathrm{I}$ each, $\$ 8$ for Io; 6 to $8 \mathrm{ft}$., I in. caliper, $75 \mathrm{cts}$. each, $\$ 6$ for 10 .

Red-flowered. $A$. rubicunda. Like the above, but the leaves are deeper green; the flowers are a showy red, and open a little later. 8 to $\mathrm{Io} \mathrm{ft}$., I $1 / 4$ in. caliper, \$I.5O each, \$Io for Io.

HORNBEAM, European. Carpinus Betulus. Large tree; trunk furrowed, bark on branches smocth and gray. 4 to $6 \mathrm{ft}$. $50 \mathrm{cts}$. each.

JUDAS TREE, or RED BUD. Cercis canadensis. Very ornamental, medium-sized tree of irregular form, with heart-shaped leaves, preceded by reddish purple flowers in May. 3 to $4 \mathrm{ft}$. $50 \mathrm{cts}$. each, $\$ 4$ for Io; 2 to $3 \mathrm{ft}$. 35 cts. each, $\$ 2.50$ for 10 .

JUNEBERRY. A melanchier botryapium. Sometimes grows 25 to 40 feet tall; generally a large shrub. Flowers white, early in April; fruit in June. I 8 to 24 in. $25 \mathrm{cts}$. each, $\$ 2.25$ for $\mathrm{I} 0$. 


\section{DECIDUOUS TREES, continued}

KENTUCKY COFFEE TREE. Gymnocladus canadensis. An erect, native tree, with rough bark, stiff, blunt shoots and feathery, bluish green leaves. 6 to $8 \mathrm{ft}$. $50 \mathrm{cts}$. each.

LARCH, European. Larix europae. An excellent, rapid-growing, pyramidal coniferous tree, compact in growth, with light green foliage; drooping in habit. 5 to $6 \mathrm{ft}$. $50 \mathrm{cts}$. each, $\$ 4$ for Io; 4 to $5 \mathrm{ft}$. 35 cts. each, $\$ 3$ for Io.

LINDEN, or Basswood. Tilia americana. A splendid, large, rapid-growing tree. Leaves are exceptionally big, and the small flowers yield a delicate fragrance. Io to I $2 \mathrm{ft}$. $\$ \mathrm{I} .25 \mathrm{each}, \$ \mathrm{IO}$ for 10 ; 6 to $8 \mathrm{ft}$. $75 \mathrm{cts}$. each, $\$ 6$ for 10 .

European. T. curopcea. A good tree of large size and symmetrical habit, with fragrant flowers. Io to $12 \mathrm{ft}$. $\$ \mathrm{I} .25$ each, $\$$ Io for Io; 8 to Io $\mathrm{ft}$. \$I each, \$9 for Io.

MAGNOLIA, or Cucumber Tree. Magnolia acuminata. A tree distinctive for its splendid form and richness of foliage; attains $5^{\circ}$ to 60 feet or more in height, and adds great attractiveness to any lawn. Large leaves; inconspicuous flowers but handsome fruit. 5 to $6 \mathrm{ft}$. $50 \mathrm{cts}$. each.

Umbrella. $M$. tripetala. Attains a height of 40 feet, with widely spreading branches, forming an open head; leaves light green, white flowers and fine fruit. 8 to Io $\mathrm{ft}$., $\$ \mathrm{I}$ each; 5 to $6 \mathrm{ft} .50 \mathrm{cts}$. each.

Soulange's. M. Soulangeana. A small but handsome tree, with spreading head, making a glorious show when covered with its numerous and large white blossoms. 4 to $5 \mathrm{ft}$. $\$ 2$ each.

Showy-flowered. $M$. speciosa. Another Chinese variety, whose white and purple flowers are also large and abundant. $4 \mathrm{ft}$. $\$ 2$ each.

Hall's Japan. M. stellata, syn. Halliana. Of dwarf habit, flowers smaller, semi-double, pure white and fragrant. 2 to $3 \mathrm{ft}$. $\$ \mathrm{I} .50$ each.

MAIDENHAIR TREE. Ginkgo biloba. A native of Japan; of medium size, exceedingly interesting, desirable and ornamental, doing well in any climate. Has peculiar, fan-shaped foliage similar to that of the Maidenhair fern. $8 \mathrm{ft}$. \$I each; 5 to $6 \mathrm{ft}$. $50 \mathrm{cts}$. each.

EUROPEAN MOUNTAIN ASH. Pyrus aucuparia. A fine, hardy tree; head dense and regular. From July till winter bears large clusters of bright scarlet berries. 8 to Io $\mathrm{ft}$. $\$ \mathrm{I}$ each.
MAPLE, Silver. Acer dasycarpum. A quick-growing, wide-spreading shade tree; foliage light green above, silverwhite beneath. Very hardy; easily transplanted; of large size. 8 to Io ft. $75 \mathrm{cts}$. each; 6 to $8 \mathrm{ft}$. $50 \mathrm{cts}$. each.

Wier's Cut-leaved. A. dasycarpum Wierii. A variety of the preceding, of graceful, drooping habit and exquisitely cut leaves. Very ornamental for lawns. 8 to ro $\mathrm{ft}$. $\$ \mathrm{I}$ each.

Japan. A. palmatum. A small tree of dense and graceful habit, attaining about 20 feet in height; foliage has artistic green and red shadings. 6 to $8 \mathrm{ft}$. \$I each.

Purple Japan. A. palmatum atropurpureum. A variety of the above, with dark purple leaves. A beautiful tree or large bush. $3 \mathrm{ft}$. $\$ 2$ each.

Striped, or Moosewood. A. pennsylvanicum, or striatum. Splendid, medium-sized tree of erect, dense form, with large, light green leaves; greenish bark striped with white. 5 to $6 \mathrm{ft}$. $50 \mathrm{cts}$. each, $\$ 4$ for ro.

Norway. Acer platanoides. A handsome tree, growing 80 to roo feet in height, sturdy, compact, vigorous; deep green leaves, turning yellow in autumn. Fine for street, park or garden, or for planting in salty soils. Io to $I 2 \mathrm{ft}$., I $I / 4$ to $I \frac{I}{2}$ in. caliper, $\$ \mathrm{I} .25$ each; 8 to Io $\mathrm{ft}$., I to $\mathrm{I} / 4 \mathrm{in}$. caliper, \$I each, \$9 for Io.

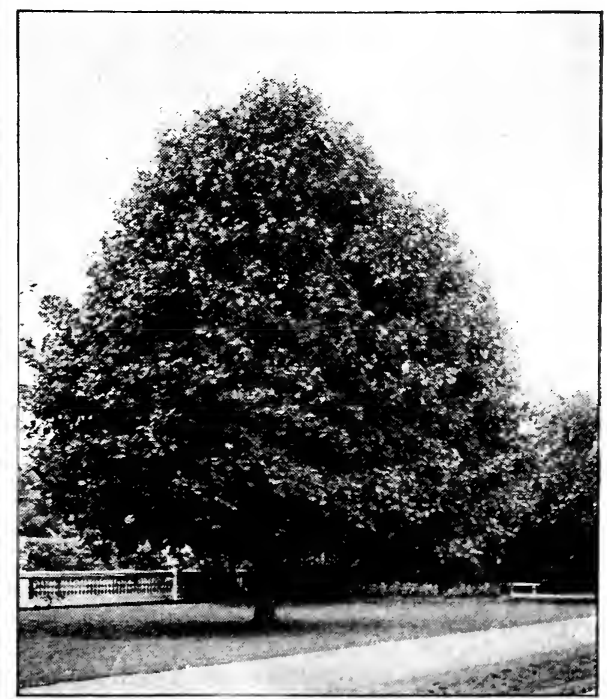

The Norway Maple is probably the best street tree 


\section{DECIDUOUS TREES, continued}

Maple, Purple or Schwedler's Norway Maple $A$. platanoides Schwedleri. Like the Norway Maple in habit, but the young foliage is a bright purple, turning dark green in late summer. 8 to $9 \mathrm{ft}$. \$I each, $\$ 9$ for Io.

Sycamore. A. pseudo-platanus. A vigorous grower, with large, spreading head, similar to the Norway Maple. Not like a Sycamore. 8 to ro $\mathrm{ft}$., $\mathrm{I}$ in. caliper, \$I each, \$9 for Io; 6 to $8 \mathrm{ft}$. 75 cts. each, $\$ 6$ for $\mathrm{I} 0$.

Sugar. A. saccharum. A native tree, lofty and grand, regular in form; one of the most valuable trees for street planting; richly colored foliage in the fall. Grows from 40 to 60 feet in height. 8 to ro $\mathrm{ft}$. $\$$ I each, $\$ 9$ for Io.

Mountain. A. spicatum. A low-growing, native species, bushy in shape; leaves resplendent in autumn in glorious tints of orange and scarlet. 4 to $5 \mathrm{ft}$. $50 \mathrm{cts}$. each, $\$ 4$ for 10.

Tartarian. A. tataricum Ginnala. Miniature, compact specimen, perfectly hardy; foliage medium-sized or small, deeply incised, turning early in autumn to brilliant scarlet. 5 to $6 \mathrm{ft}$. 50 cts. each, $\$ 4$ for I0; 4 to $5 \mathrm{ft}$. 40 cts. each, $\$ 3$ for 10.

OAK, Pin. Quercus palustris. A stately and elegant tree, distinguished by its fine growth and the drooping tendency of its branches. The leaves are deeply cut, turning red in autumn. A great street tree. $2 \mathrm{1} / 2$ to 3 in. caliper $\$ 2$ each; 8 to ro ft., 2 in. caliper, $\$ 1.50$.

Chestnut. $Q$. prinus. Large, roughbarked; thick, pale green, chestnutlike foliage. 8 to ro $\mathrm{ft}$. $\$ \mathrm{I} .50$ each.

Red. $Q$. rubra. A particularly good Oak, attaining large size, with a fine, round top. Foliage is bright, maturing into rich, deep green. A rapid grower; bears large acorns. 8 to Io ft., 2 in. caliper, $\$ \mathrm{I} .50$ each.

OLEASTER, or Bohemian Olive. See Shr ubs, page 14.

ORIENTAL PLANE. Platanus orientalis. Good for street planting. Rapidgrowing; hardy. 6 to $8 \mathrm{ft} .75 \mathrm{cts}$. ea.

POPLAR. (Balsam, or Balm of Gilead.) Populus candicans. A tall, slender shade tree; grows with remarkable rapidity; has quite spreading branches and large, glossy foliage. 8 to ro ft. $75 \mathrm{cts}$. each, $\$ 5$ for Io; 6 to $8 \mathrm{ft}$. 50 cts. each, $\$ 4$ for 10.

Carolina. $P$. carolinensis. Valuable for street planting on account of rapid growth. Form pyramidal; leaves large, glossy, serrated, pale to deep green. 6 to $8 \mathrm{ft}$. $50 \mathrm{cts}$. ea., $\$ 4$ for Io.
Poplar, Lombardy, or Italian. P. nigra italica. A tall, close-growing tree, unique in habit. Its dark green leaves are triangular, with serrated edges. Fine in landscape work to break monotonous outlines. Io to $12 \mathrm{ft}$. 75 cts. each, $\$ 5$ for $\mathrm{ro} ; 8$ to ro $\mathrm{ft}$. 50 cts. each, $\$ 4$ for Io; 6 to $8 \mathrm{ft}$. 35 cts.each, $\$ 2.50$ for 10 .

PLUM, American. Prunus americana. Small, spreading, usually thorny tree, with gray-brown branches; flowers white, in small clusters, appear before leaves; fruit small, reddish yellow. 4 to $6 \mathrm{ft}$. $35 \mathrm{cts}$. each.

Purple-leaved. $P$. Pissardi. Fine form; purple leaves, wine-red fruit. A good purple-leaved tree, retaining its color until fall. 4 to $6 \mathrm{ft}$. $50 \mathrm{cts}$. each.

SNOWDROP, or Silver Bell Tree. See Shrubs, page I5.

SUMAC, Staghorn. Rhus typhina. A small tree, with red fruit and brilliant foliage in autumn. New growth has the appearance of a stag's horn, as it is densely covered with velvety down; a rapid-growing tree, greatly improved by constant pruning. 5 to 8 ft. $35 \mathrm{cts}$. each; 3 to $4 \mathrm{ft} .25 \mathrm{cts}$. each, $\$ 2.25$ for 10 .

SWEET GUM, or Bilsted. Liquidambar styraciflua. One of the best native lawn trees. Of medium size, moderate growth, with corky bark and starshaped foliage. Tender in the North when small. 4 to $5 \mathrm{ft}$. 50 cts. each.

TULIP TREE. Liriodendron tulipifera. A splendid, stately, rapid-growing tree of pyramidal habit; leaves light green, fiddle-shaped; exquisite tuliplike flowers. 4 to $6 \mathrm{ft}$. $50 \mathrm{cts}$. each.

VARNISH TREE. Kolreuteria paniculata. A small, globe-headed tree, fairly hardy and especially valuable for its golden flowers, which come in July after other trees. 8 to Io $\mathrm{ft}$. SI $_{\text {I }}$ each; 4 to $5 \mathrm{ft}$. $50 \mathrm{cts}$. each.

WILLOW, Wisconsin weeping. Salix babylonica. A useful and ornamental tree, of rapid growth and fine habit; hardy; adapted to many soils. The leaves are quite narrow, tapering to a point, and bright green in color. A familiar and picturesque tree. 8 to ro $\mathrm{ft}$. $50 \mathrm{cts}$. each.

YELLOW-WOOD. Virgilia lutea, or Cladrastis tinctoria. Fine American tree; rounded head. Light green foliage, with long racemes of white, scented flowers. 6 to $8 \mathrm{ft} .75 \mathrm{cts}$. each; 5 to $6 \mathrm{ft}$. $50 \mathrm{cts}$. each. 


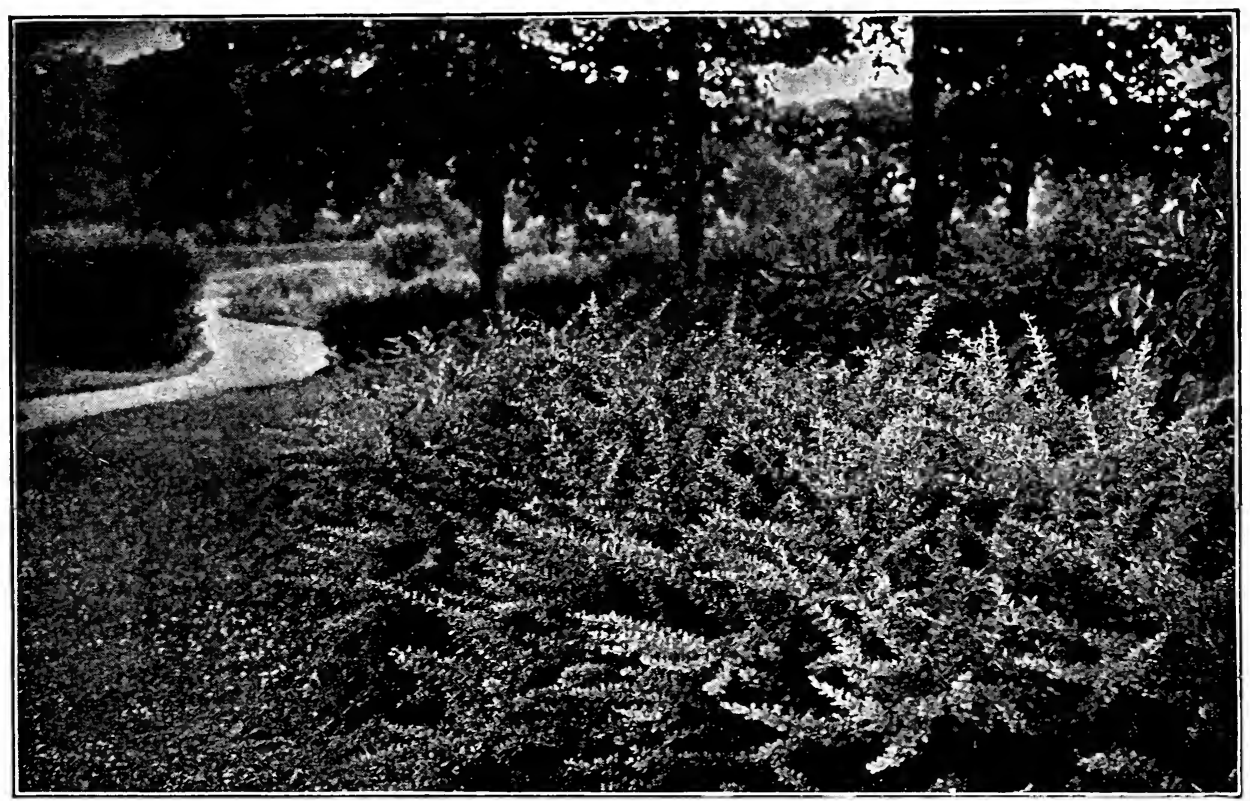

Thunberg's Barberry makes one of the finest untrimmed hedges

\section{Deciduous Shrubs}

ALDER, BLACK, or Winterberry. Ilex verticillata. A well-branched, hardy shrub, producing quantities of bright red berries, which keep in good condition well into January. I 2 to 18 in. 25 cts. each, $\$ 2.25$ for Io.

ALMOND, Double-flowering. Prunus Japonica alba $f l$. pl. A Japanese low shrub, with handsome, double or semidouble white flowers. $3 \mathrm{ft}$. 5oc. each.

Pink-flowering. P. Japonica rosea $\mathrm{fl}$. pl. As above, with rose-colored flowers. 2 to $3 \mathrm{ft}$. 50 cts. each.

ALTHEA, or Rose of Sharon. Hibiscus syriacus. Splendid, free-growing, flowering shrub, with single and double flowers in August and September. 2 to $3 \mathrm{ft}$. $35 \mathrm{c}$. ea., $\$ 2.50$ for Io.

Amplissima. Double; dark rose.

Anemonæflorus. Double; bright red.

Boule de Feu. Double; bright red.

Carnea plena. Semi-double; rose.

Colestis. Single; blue.

Elegantissima. Semi-double; white.

Pulcherrima. Semi-double; rosy white.

Rubis. Single; red.

Speciosa. Double; fleshy white.

Snowdrift. Single; pure white.

Totus albus. Single; pure white.

ANGELICA TREE, or Hercules' Club. Aralia spinosa. Native deciduous shrub, with stout, prickly stems and compound green leaves. Excellent. 5 to $6 \mathrm{ft}$. $50 \mathrm{cts}$. each, $\$ 3.50$ for Io.
Angelica Tree, Five-leaved. A. pentaphylla. Large shrub, with five-parted, shining leaves and inconspicuous white flowers. Valuable for semitropical effect. 2 to $3 \mathrm{ft}$. $25 \mathrm{cts}$. each, $\$ 2.25$ for IO.

ANDROMEDA. Andromeda ligustrina. Many-branched, bearing clusters of white flowers. A native shrub growing in wet places. 2 to $3 \mathrm{ft}$. 50 cts. each.

Racemosa. Leucothoe racemosa. Ornamental shrub, growing 6 to 8 feet, with erect branches; flowers white; rich autumnal foliage. 5 to $6 \mathrm{ft}$. 50 cts. each, $\$_{3} .50$ for Io.

\section{FLOWERING CRAB APPLES}

Ve want to call special attention to the following list of Double- and Singleflowering Crabs, as they are of wonderful beauty. The Flowering Crabs are mostly small trees, with smooth bark. The leaves are dark green and oval; the flowers generally snall, white or blush in color, borne on slender stems; fruit small and round.

4 to $6 \mathrm{ft} .75 \mathrm{cts}$. each, $\$ 5$ for 10

Arnold's. Pyrus Arnoldiana. One of the best of the Floribunda type. Flowers decidedly pink when they first open. Comparatively low-growing and spreading but by no means dwarf.

Kaido. From Japan. Flowers single; white and pink; fruit small, in clusters. 


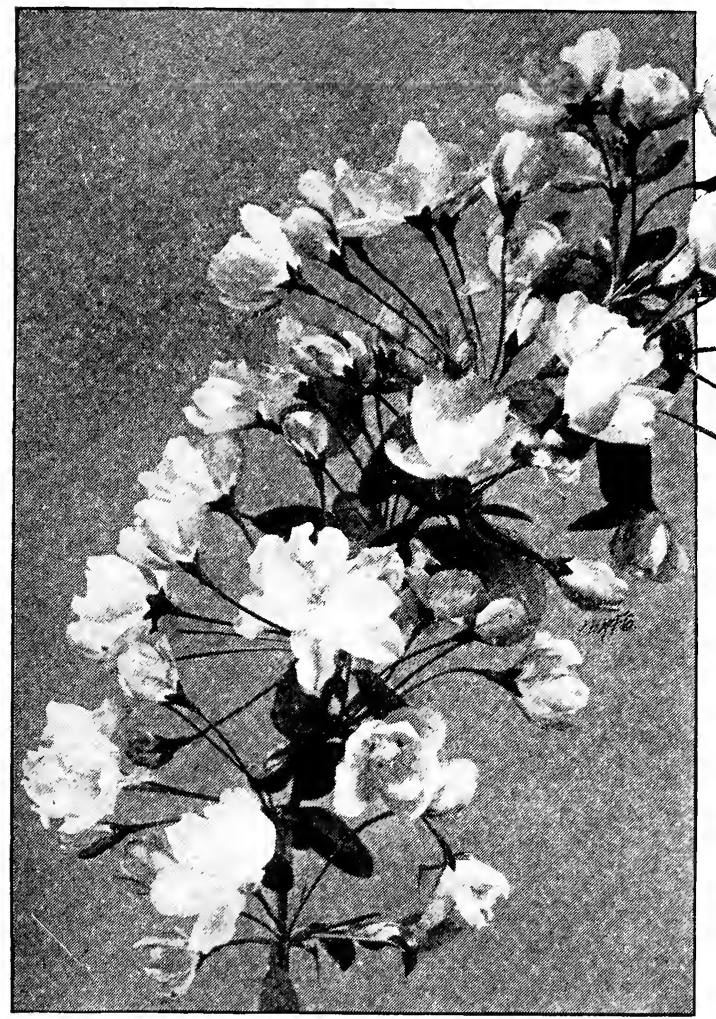

Spray of fragrant Flowering Crab Apples

\section{AZALEA}

One of the most ornamental and exquisite of the flowering shrubs, bearing large and numerous showy, brilliantly colored flowers. Especially good for decorative purposes. They require a fine, deep soil and a sheltered position.

Arborescens. Flowers white or tinged rose, fragrant. June andJuly I 8 to 24 in. 50 cts. each, $\$ 4.50$ for IO; I2 in. 35 cts. each, $\$ 3$ for Io.

Calendulacea. Flowers orangeyellow or flame-red, of ten 2 inches broad. May and June. I 8 to 24 in. 50 cts. each, $\$ 4.50$ for Io; 12 in. 35 cts. each, $\$ 3$ for 10.

Mollis. Flowers yellow and different shades of red. 18 to 24 in. 50 cts. each, $\$ 4.50$ for Io; 12 to I 5 in. 40 cts., each $\$ 3.50$ for 10 .

Nudiflora. Flowers pink to nearly white. April and May. 18 to 24 in. 50 cts. each, $\$ 4.50$ for I0; I 2 in. 35 cts. each, $\$ 3$ for Io.

Vaseyi. Soft pink. One of the best and very hardy. April and May. 24 in. 75 cts. each, $\$ 6$ for 10 ; 10 to

FLOWERING CRAB APPLE, continued

American Garland, or Wild Crab. $P$. coronaria. Larger than most of the Crabs; flowers pink, fragrant; late.

Floribunda. Single flowers, changing from carmine in the bud to white when open; fruit small and ornamental. A somewhat variable tree.

Atrosanguinea. Flowers bright crimson, borne in great quantities.

Betchel's Double-flowering. P. Ioensis. One of the most beautiful late blooming Crab Apples yet introduced. Double, pink flowers of large size; very fragrant.

Niedwetskyana. A Japanese variety. Growth is like the ordinary Apple, but not so big. Flowers rosy pink, quite different from the others.

Parkman's. P. Parkmanii. Habit dwarf and compact. Foliage dark green. Flowers double, dark rose, last a long time and retain color until they drop.

Scheideckeri. Flowers changing from red in bud to pink or rose; fruit yellow.

Chinese Double White-flowered. $P$. spectabilis, var. $f l$. pl. alba. Double, white, fragrant flowers in clusters.

Chinese Double Rose-flowered. $P$. spectabilis, var. $f$. pl. rosea. Has many fragrant, rose-colored flowers.
24 in. 50 cts. each, $\$ 4.50$ for Io.

Viscosa. Flowers white or tinged rose, I $1 / 2$ to 2 inches long; fragrant. June and July. 18 to 24 in. 50 cts. each, $\$ 4.50$ for Io; I 2 to I 8 in. 35 cts. each, $\$ 3$ for 10 .

Pontica, Ghent Hybrids. Ten named varieties, colors ranging from light to dark yellow, orange and red. 24 to 30 in. $\$$ I each, $\$ 8$ for Io.

\section{BARBERRY}

Japanese. Berberis Thunbergii. Exceptionally good for hedges; compact growth, thorny branches; foliage dark green, changing to red in autumn. Has crimson berries holding all winter, which, with a reddish brown bark, produce a fine winter effect. I 8 to 24 in. 25 cts. each, $\$$ I.75 for IO, \$I2 per IOO; I 2 to 18 lin. I 5 cts. each, $\$$ I.25 for IO, $\$$ Io per IOO.

Common. B. vulgaris. A sturdy shrub of medium height; golden yellow flowers, and later scarlet fruit in clusters. $2 \mathrm{ft}$. 25 cts. each, $\$ 2.25$ for 10 .

Purple-leaved. B. purpurea. Grows from 5 to ro feet high, with purple foliage. 2 to $3 \mathrm{ft} .25 \mathrm{cts}$. each, $\$ 2.25$ for IO. 


\section{DECIDUOUS SHRUBS, continued}

BLUE SPIRAA. Caryopteris mastacanthus. A dense and compact shrub, 2 to 3 feet in height; leaves dusty green; flowers dull blue, in late summer. Somewhat tender in the North. I 2 to 18 in. 25 cts. each, $\$ 2.25$ for Io.

BLUEBERRY, or Swamp Huckleberry. Vaccinium corymbosum. Bush 3 to ro feet high; foliage good, a fine red in autumn; twigs red in winter; excellent fruit. 2 to $3 \mathrm{ft} .75 \mathrm{cts}$. each.

BUCKTHORN. Rhamnus catharticus. A fine bush, with spiny branches, dark green leaves, which last late, and black berries; makes excellent hedge. 3 to $4 \mathrm{ft}$. $25 \mathrm{cts}$. each, $\$ 2.25$ for IO; 2 to $3 \mathrm{ft}$. $20 \mathrm{cts}$. each, $\$ \mathrm{I} .75$ for 10.

Alder-leaved. $R$. alnifolia. A tall shrub, with bright leaves; many red berries which change to black in winter. 4 to $5 \mathrm{ft} .35 \mathrm{cts}$. each, $\$ 3$ for io.

Sea Buckthorn. Hippophce rhamnoides. Does well near salt water. Has grayish white foliage and showy fruits. 3 to $4 \mathrm{ft}$. $35 \mathrm{cts}$. each, $\$ 3$ for $10 ; 2$ to $3 \mathrm{ft}$. $25 \mathrm{cts}$. each, $\$ 2.25$ for Io.

CALICO BUSH. Kalmia latifolia. An American evergreen with sparkling foliage; dense clusters of pink or white flowers in spring. With ball. I 2 to 15 in. 50c. eac., $\$ 4$ for I0; 2 to $21 / 2 \mathrm{ft}$. $\$ 1.75$ ea.

CAROLINA ALLSPICE, or Sweetscented Shrub. Calycanthus floridus. Grows 6 to 8 feet; foliage rich green; flowers purple, fragrant. 2 to $3 \mathrm{ft}$. $25 \mathrm{cts}$. each.

CHOKE BERRY. Pyrus arbutifolia. Low shrub; good foliage and red or black fruit. I 8 to 24 in. $25 \mathrm{cts}$. each, $\$ 2.25$ for 10 .

DESMODIUM, or Tick Trefoil. Desmodium penduliflorum. A tall shrub; rose-colored or purple flowers in September. 3 to $4 \mathrm{ft}$. 25 cts. each, $\$ 2.25$ for ro.

DEUTZIA, Slender-branched. Deutzia gracilis. A hardy, dwarf shrub, with luxuriant leaves and pure white flowers in racemes, blooming in June. 12 to 15 in. 25 cts. each, $\$ 2.25$ for 10 .

Gracilis rosea. Bell-shaped flowers, delicate rose-color on outside of petals. 24 in. 25 cts. each, \$2.25 for 10 .

Parviflora. White flowers in flat corymbs. 18 to 24 in. $25 \mathrm{cts}$. each, $\$ 2.25$ for 10 .

Scabra, White. Double white flowers in hanging racemes; foliage oval, rough underneath. 2 to $3 \mathrm{ft}$. 25 c. ea., $\$ 2.25$ for 10 .
Deutzia scabra, Double Pink. Flowers decidedly tinged with pink. 2 to $3 \mathrm{ft}$. 25 cts. each, $\$ 2.25$ for 10 .

Fortunei. The best of the single white Deutzias. 2 to $3 \mathrm{ft} .25 \mathrm{c}$. ea., $\$ 2.25$ for Io.

Pride of Rochester. A good variety, with double white flowers, slightly tinted with rose. 2 to $3 \mathrm{ft}$. $25 \mathrm{cts}$. each, $\$ 2.25$ for Io.

DOGWOOD, Variegated. Cornus alba elegantissima. Dwarf; foliage margined white, or entirely silvery white. 2 to $3 \mathrm{ft}$. $25 \mathrm{cts}$. each, $\$ 2.25$ for Io.

Common or Flowering. C. florida. One of our most beautiful and showy spring-flowering shrubs. 2 to $3 \mathrm{ft}$. 25 cts. each, $\$ 2.25$ for Io.

Red-flowering. C. florida rubra. A variety of the foregoing, with bright pink flowers. 18 to 24 in. 75 cts. each.

Cornelian Cherry. C. Mas. A large, thick shrub; bright yellow flowers in early spring before the leaves. 4 to $5 \mathrm{ft}$. $35 \mathrm{cts}$. each, $\$ 3$ for Io; 3 to $4 \mathrm{ft}$. 25 cts. each, $\$ 2.25$ for 10 .

Gray. C. paniculata. A native shrub; leaves bright green above, whitish beneath. Profusion of white flowers followed by white berries in August. 24 in. 35 cts. each, $\$ 3$ for 10.

Silky. Cornus sericea. A tall shrub; twigs reddish purple. Flowers white, followed by bluish white fruit. 3 to 4 ft. 25 cts. each, $\$ 2.25$ for 10 .

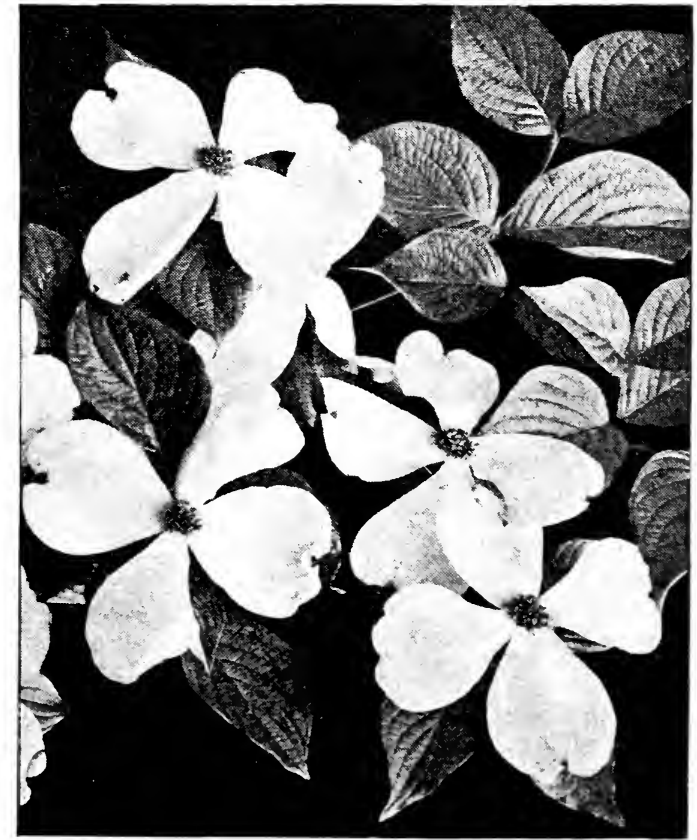

White-flowering Dogwood 


\section{DECIDUOUS SHRUBS, continued}

Dogwood, Red Osier. C. alba. Mediumsized; dark red bark, white berries. 3 to $4 \mathrm{ft}$. $25 \mathrm{cts}$. each, $\$ 2.25$ for ro.

Scarlet Osier. C. alba, var. Sibirica. The best of all the red-twigged Osiers. If cut back once in three or four years it becomes a mass of color all winter. 2 to $3 \mathrm{ft} .25 \mathrm{cts}$. each, $\$ 2.25$ for $\mathrm{I} 0$.

European Red Osier. $C$. sanguinea. Blood-red branches, with almost black fruit. $3 \mathrm{ft} .25 \mathrm{cts}$. each, $\$ 2.25$ for Io.

Yellow-branched. C. stolonifera, var. flaviramea. Like the Red Osier, but with bright yellow bark in winter. 2 to $3 \mathrm{ft}$. $25 \mathrm{cts}$. each, $\$ 2.25$ for Io.

ELDERBERRY, Common American or Sweet. Sambucus canadensis. A high bush with jointed branches and compound leaves. Small, fragrant flowers followed by black berries. 3 to $4 \mathrm{ft} .25 \mathrm{cts}$. each, $\$ 2.25$ for $\mathbf{I}$.

Golden. S. aurea. Luminous yellow leaves. A sturdy grower. 18 to 24 in. 25 cts. each, $\$ 2.25$ for 10 .

Red-berried. S. racemosa. Panicles of white flowers in spring, followed by bright red berries. 2 to $3 \mathrm{ft}$. $35 \mathrm{cts}$. each, $\$ 3$ for 10 .

EUONYMUS, European Burning Bush, or Spindle Tree. Euonymus europaus. A shrub, or small tree, sometimes growing 20 feet high. The fruit in late summer is abundant and attractive. 4 to $5 \mathrm{ft} .35 \mathrm{cts}$. each, $\$ 2.50$ for Io; 2 to $3 \mathrm{ft} .25 \mathrm{c}$. ea., $\$ 2.25$ for Io.

Japanese. E. Bungeanus. Of symmetrical growth, with abundant and showy fruit. 4 to $5 \mathrm{ft}$. $35 \mathrm{cts}$. each, $\$ 2.50$ for IO.

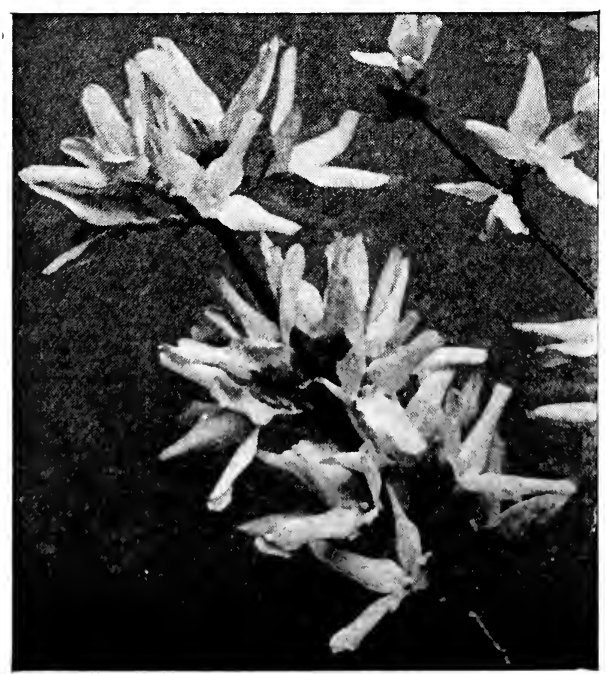

Golden Bell
GOLDEN BELL, Fortune's. Forsythia Fortunei. A medium-sized shrub, with slender branches and drooping, bright yellow flowers in early spring. 4 to $5 \mathrm{ft}$. $35 \mathrm{cts}$. each, $\$ 3$ for I $; 3$ to 4 ft. 25 cts. each, $\$ 2.25$ for Io.

Hybrid. $F$. intermedia. A very hardy variety, with bright golden flowers; foliage deep green. A fine shrub. 3 to $4 \mathrm{ft}$. $5 \mathrm{cts}$. each, $\$ 2.25$ for $\mathrm{I} 0$.

Weeping. F. suspensa. The growth is decidedly drooping but the foliage not so good as the others. 3 to $4 \mathrm{ft}$. 25 cts. each, $\$ 2.25$ for 10 .

FRINGE TREE. Chionanthus virginica. A desirable large shrub; leaves dark green; clusters of drooping, fragrant, white flowers; bluish, plum-like fruit. 2 to $3 \mathrm{ft} .35 \mathrm{cts}$. each.

GROUNDSEL TREE, or Salt Bush. Baccharis halimifolia. Spreading shrub, with dark green foliage. Fluffy white seed-pods in autumn. 2 to $3 \mathrm{ft}$. $25 \mathrm{cts}$. each, $\$ 2.25$ for 10 .

HONEYSUCKLE, White. Lonicera bella albida. Erect, shrubby habit; fragrant, white flowers and bright red berries. 3 to $4 \mathrm{ft} .25 \mathrm{cts}$. each, $\$ 2.25$ for 10.

Candida. L. bella candida. Another good Bush Honeysuckle, with an abundance of pure white flowers. 3 to $4 \mathrm{ft} .25 \mathrm{cts}$. each, $\$ 2.25$ for $\mathrm{I} 0$.

Atrorosea. L. bella atrorosea. A beautiful Bush Honeysuckle, with bright rosy flowers. The fruit is abundant, and attractive to the birds. 3 to $4 \mathrm{ft}$. 25 cts. each, $\$ 2.25$ for 10 .

Morrowii. A fine Japanese variety of spreading and symmetrical habit. Pure white flowers and bright red fruit. 2 to $3 \mathrm{ft} .25 \mathrm{c}$. each, $\$ 2.25$ for 10.

Ruprechtiana. From Manchuria; valuable for its showy red berries. 2 to $3 \mathrm{ft}$. $25 \mathrm{cts}$. each, $\$ 2.25$ for Io.

HYDRANGEA, Everblooming. $H y$ drangea arborescens. A native species of quick and sturdy growth, suitable for extensive plantations. $3 \mathrm{ft} .25 \mathrm{cts}$. each, $\$ 2.25$ for 10 .

Hills of Snow. H. arborescens sterilis. One of the finest shrubs for lawn and mass planting. Medium-sized, hardy; splendid foliage, with great clusters of dazzling white flowers, changing to green with the season. Heavy, 2 to $3 \mathrm{ft}$., $25 \mathrm{cts}$. each, $\$ 2.25$ for $\mathrm{I} 0$.

Panicled. H. paniculata. An earlyblooming Hydrangea. Somewhat like following variety, but the flowerclusters are more open and interspersed with small, fertile flowers. 2 to $3 \mathrm{ft}$. $25 \mathrm{cts}$. each, $\$ 2.25$ for $\mathrm{IO}$. 
DECIDUOUS SHRUBS, continued

Hydrangea, Large-flowered. $H$. paniculata grandiflora. Bush of medium height; flowers in immense, pointed, creamy white clusters, changing to reddish pink blooms in August and September, and the flowers keep in good condition a long time. Requires close pruning in the spring. 2 to $3 \mathrm{ft} .25 \mathrm{cts}$. each, $\$ 2.25$ for Io.

JAPAN GLOBE FLOWER, or Japanese Rose. Kerria japonica. Three to 4 feet tall; slender, bright green branches, which keep their color all winter. In spring it bears masses of showy, single, yellow flowers. I 8 to 24 in. 25 cts. each, $\$ 2.25$ for 10 .

Double-flowering. $K$. japonica $f$. pl. Like the above, but with double, yellow blossoms. 2 to $3 \mathrm{ft} .25 \mathrm{cts}$. each, $\$ 2.25$ for Io.

Variegated-leaved. $K$. japonica variegata. A variety of the preceding, with variegated leaves; of dwarf habit. I2 to I 8 in. 25 cts. each, $\$ 2.25$ for Io.

White Kerria. Rhodotypos kerrioides. An excellent mediumsized shrub, with very handsome, dark green foliage and with single white flowers in late May and abundant fruit. $3 \mathrm{ft} .35 \mathrm{cts}$. each, $\$ 3$ for IO; 2 to $3 \mathrm{ft} .25 \mathrm{c}$. each, $\$ 2.25$ for Io.

\section{LILACS}

The Lilacs are probably as well known and fully as popular as any of the flowering shrubs. The bushes are generally quite tall and are very vigorous. The Lilacs make a great showing when massed in groups, but, if the best effects are desired, care should be taken in the arrangement of varieties. Some of the species make handsome specimen trees. The foliage is of good texture and various shades of green. The flowers are of various colors, both single and double, appearing in showy clusters in May, and are very fragrant.

Tree Lilac. Syringa japonica. A small and symmetrical tree, native of Japan, with glossy, dark green foliage. Flowers creamy white, in great panicles, opening much later than other Lilacs. 4 to $5 \mathrm{ft}$. 50 cts. each.

Persian. S. chinensis or Rothomagensis. A low, good-size shrub, with graceful, slender branches and small, narrow leaves. Flowers bright purple, in large panicles in May. 2 to $3 \mathrm{ft}$. $35 \mathrm{cts}$. each, $\$ 3$ for Io.

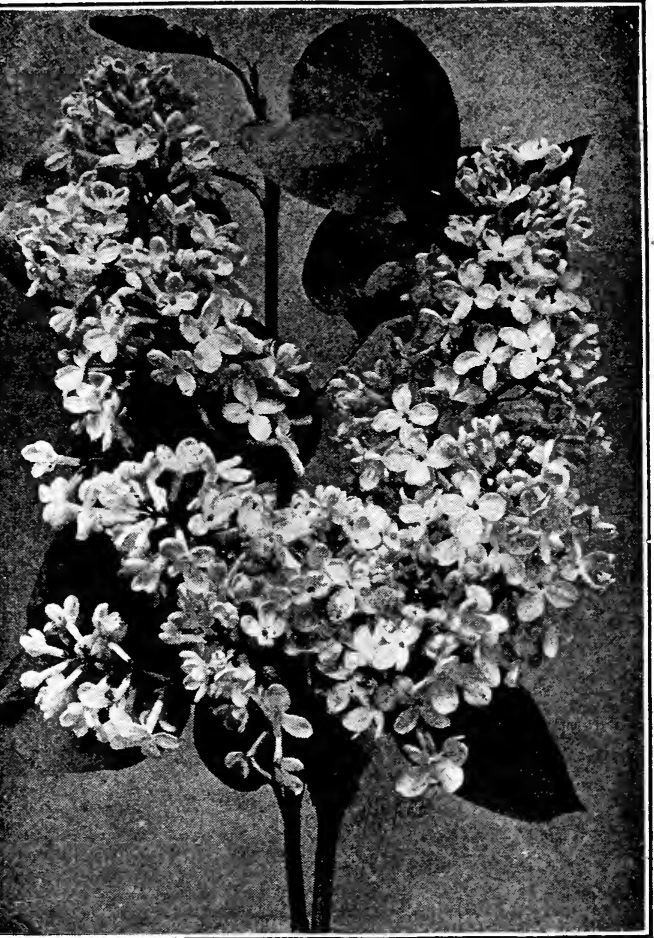

Single Lilac, Charles $X$ (see page I4)

White Persian. S. chinensis alba. Similar to the preceding, but with white flowers and of more delicate growth. 3 to $4 \mathrm{ft}$. $35 \mathrm{cts}$. each, $\$ 3$ for Io.

Sougeana. Like the above, but with much darker flowers, almost blood-red.

Villosa. Flowers pinkish lilac, fragrant. They open two weeks later than the common Lilacs. 2 to $3 \mathrm{ft} .35 \mathrm{cts}$. each, $\$ 3$ for Io.

Common. S. vulgaris. This grand old species grows to a high bush, 8 to I2 feet; the leaves are heart-shaped and bright green; the clusters are long and cf bluish purple, borne in wonderful profusicn in May. 3 to $4 \mathrm{ft} .35 \mathrm{cts}$. each, $\$ 2.50$ for 10 .

Common White. S. vulgaris alba. Of about the same habit as the preceding but the flowers are pure white and very fine. 3 to $4 \mathrm{ft}$. $35 \mathrm{c}$. ea., $\$ 2.50$ for 10 .

The following named varieties of Lilacs (Syringa vulgaris) are selected from a long list and are fully recommended. Can be furnished in stocky plants from 2 to $3 \mathrm{ft}$., according to variety, for $5^{\circ} \mathrm{cts}$. each, $\$ 4.5^{\circ}$ for 10 .

Large-flowered White. S. alba grandiflora. Single flowers, large, pure white.

Frau Bertha Dammann. Flowers medium size, single, pure white, in immense trusses. 


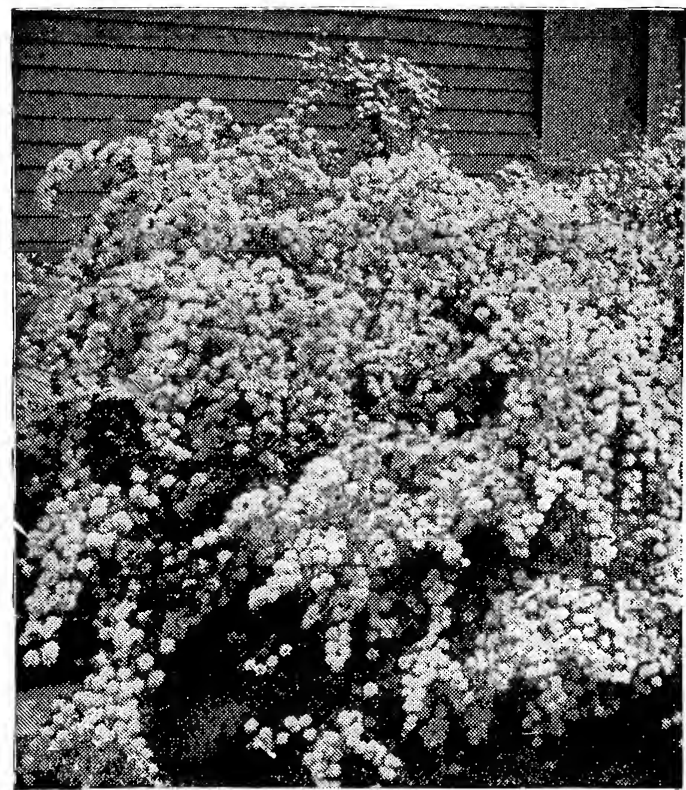

Spiræa Van Houttei (see page I5)

\section{LILACS, continued}

Charles X. A strong, rapid grower. Foliage large and glossy; flowers reddish purple, in big, loose trusses.

Congo. Flowers large; wine-red; very double and compact.

Maxime Cornu. Double; rose-colored.

Marie Legraye. Panicles of pure white, single, flowers fragrant.

Mme. Lemoine. Double; white flowers.

Souvenir de Ludwig Spæth. Single; large panicles of dark reddish purple flowers.

NINEBARK. Physocarpus opulifolius. A tall, vigorous shrub, with spreading branches and clustersof showy, whitish flowers in early summer. 2 to $3 \mathrm{ft}$. 25c. ea., \$2.25 for IO.

Golden. $P$. opulifolius aurea. Tall and slender, with arching branches and bright yellow leaves. 2 to $3 \mathrm{ft} .25 \mathrm{cts}$. each, \$2.25 for IO.

NEW JERSEY TEA. Ceanothus americana. A low, spreading shrub; white flowers in dense clusters in midsummer. I 8 to 24 in. 25 cts. each, $\$ 2.25$ for Io; I 2 to $\mathrm{I} 8$ in., $20 \mathrm{cts}$. each, $\$ \mathrm{I} .75$ for Io.

OLEASTER, or Bohemian Olive. Eleagnus hortensis. Graceful, attractive small tree, with slightly spiny branches and yellow, very fragrant flowers in clusters in June. 4 to $5 \mathrm{ft}$. 35 cts. each, $\$ 2.50$ for IO.

Japanese. E. longipes. Yellow ish white, fragrant flowers, and red berries dotted with gold; edible. 3 to $4 \mathrm{ft}$. 35 cts. each, $\$ 2.50$ for Io.
PEARL BUSH. Exochorda grandiflora. A large shrub, with bright green leaves and pure white flowers in small clusters. 3 to $4 \mathrm{ft} .25 \mathrm{cts}$. each, $\$ 2.25$ for Io.

PEA TREE. Caragana arborescens. A large shrub, with bright green, compound leaves and numerous, bright yellow, pea-shaped flowers. 3 to $5 \mathrm{ft}$. $35 \mathrm{cts}$. each, $\$ 2.50$ for Io; 2 to $3 \mathrm{ft} .25 \mathrm{cts}$. each, $\$ 2.25$ for Io.

PRIVET, Amoor River. Ligustrum amurense. A hardy and vigorous hedge plant, bearing shearing well. Dark, lustrous green foliage; white flowers in erect heads in June and July. 2 to $3 \mathrm{ft}$. 20c. ea., \$I.50 for IO, \$I 2 per Ioo. Japanese. L. ibota. A fine variety growing freely in all soils. It is a robust grower, compact and regular in form; bears numerous clusters of large, white, fragrant flowers. The foliage is good and the plant bears abundant fruit. 2 to $3 \mathrm{ft}$. $25 \mathrm{c}$. each, $\$ \mathrm{I} .5 \mathrm{O}$ for IO, $\$$ I 2 per IOO; I8 to 24 in. I5c. each, \$I.25 for IO, \$IO per IoO.

Regel's. L. ibota Regelianum. A lowgrowing form, with spreading habit and symmetrical growth. Flowers numerous, and abundant fruit which hangs late in season. Prices same as Japanese Privet.

California. L. ovalifolium. The most popular hedge plant. Foliage beautiful olive-green and lasting. Plants trim easily and are of fine habit. 3 to $4 \mathrm{ft}$. $20 \mathrm{cts}$. each, $\$ \mathrm{I} .50$ for IO, \$IO per I OO; 2 to $3 \mathrm{ft}$. I $5 \mathrm{cts}$. each, $\$ \mathrm{I} .25$ for Io, $\$ 8$ per Ioo.

PLUM, Double-flowering. Prunus triloba, $f$. $p l$. A strong-growing shrub, with double, soft pink flowers and slender branches. 2 to $3 \mathrm{ft}$., $50 \mathrm{cts}$. each.

QUINCE, Japan White. Pyrus japonica alba. Thorny, widely branched shrub from Japan. Large, showy, white flowers in early spring; fruit green, speckled and very hard. I 2 to 24 in. 25 cts. each, $\$ 2.25$ for Io.

Red. P. japonica cardinalis. Flowers brilliant scarlet. I 8 to 24 in. 25 cts. each, $\$ 2.25$ for Io.

Rose. P. umbilicata rosea. Large, rosered flowers. 2 to $3 \mathrm{ft} .25 \mathrm{cts}$. each. $\$ 2.25$ for IO.

Mixed Colors. 2 to $3 \mathrm{ft} .25$ cts., $\$ 2.25$ for Io.

SCOTCH BROOM. Cytisus scoparius. A stout shrub, with the greatest profusion of yellow flowers in June. A famous plant. It is not very hardy in the North. 2 to $3 \mathrm{ft}$. $25 \mathrm{cts}$. each, $\$ 2.25$ for IO. 


\section{DECIDUOUS SHRUBS. continued}

SORREL TREE, or Sourwood. Oxydendron arboreum. A handsome, small tree, with oblong, pointed leaves; flowers white, in loose cluster at branch-ends; somewhat tender in the North. 2 to $3 \mathrm{ft}$. 75 cts. each.

SPIREA, Anthony Waterer. Spirca Bumalda. Low-growing; unsurpassed for border fronts. Produces, in late summer, flat heads of brilliant rosy blossoms. If the flower-stems are clipped from time to time the plants will bloom until frosts cut them down. 24 in. 25 c. each, $\$ 2.25$ for 10.

Billard's. S. Billardi. Rose-colored flowers; blooms nearly all summer; strong-growing. 3 to $4 \mathrm{ft}$. $25 \mathrm{cts}$. each, $\$ 2.25$ for Io.

Japanese Red. S. japonica callosa rubra. Fine variety, with deep rosered flowers in compact corymbs, in summer. 3 to $4 \mathrm{ft}$. $25 \mathrm{cts}$. each, $\$ 2.25$ for IO.

Plum-leaved. S. prunifolia. Plant is graceful and tall, with slender branches and excellent foliage. Flowers in April and May are small and double; white. 3 to $4 \mathrm{ft}$. $25 \mathrm{cts}$. each, $\$ 2.25$ for IO.

Thunberg's. S. Thunbergii. Dwarf; branches drooping; flowers small, white; one of the earliest. $3 \mathrm{ft} .25 \mathrm{cts}$. each, \$2.25 for Io.

Bridal Wreath. S. Van Houttei. Considered by many the finest variety cultivated. Branches spreading, covered their entire length with dark green leaves and masses of dense clusters of white flowers in May and early June. 4 to $5 \mathrm{ft}$. $35 \mathrm{cts}$. each, $\$_{3}$ for I0; 3 to $4 \mathrm{ft} .25 \mathrm{cts}$. each, $\$ 2.25$ for IO.

Hybrid Snow Garland. S. arguta. A showy, sturdy shrub, of dwarf habit; very free-flowering; flowers clear white, appearing early in May. 2 to $3 \mathrm{ft} .25 \mathrm{cts}$. each, $\$ 2.25$ for 10 .

Chinese. Stephanandra flexuosa. A low-growing shrub, with drooping branches covered with glossy green leaves, distinctly marked and tinted with red at edges. Top sometimes winter-kills in the North. $3 \mathrm{ft} .25 \mathrm{cts}$. each, $\$ 2.25$ for Io.

SPICE BUSH. Lindera Benzoin. A goodsized shrub; handsome foliage and early yellow flowers. Thrives best in sandy or peaty soil. 2 to $3 \mathrm{ft} .25 \mathrm{cts}$. each, $\$ 2.25$ for Io.

ST YRAX Japonica. A good-sized shrub, native of Japan. Foliage is deep green and the flowers pure white and fragrant, appearing in early summer. 2 to $3 \mathrm{ft}$ : 50 cts. each.
SNOWBERRY, White. Symphoricarpos racemosus. A well-known shrub of slender, graceful habit; flowers small, dainty pink, in loose clusters, followed by large, white, waxy berries that remain on the plant until severe frost. 2 to $3 \mathrm{ft} .25 \mathrm{cts}$. each, $\$ 2.25$ for Io.

Red-fruited, Indian Currant, or Coral Berry. S. vulgaris. A lowgrowing and graceful bush. Leaves, flowers and fruit are small, but fruit consists of heavy clusters of bright red berries, which hang on all winter. $2 \mathrm{ft} .25 \mathrm{cts}$. each, $\$ 2.25$ for IO.

SNOWDROP, or Silver Bell Tree. Halesia tetraptera. A handsome, desirable tree or shrub, having delicate white, bellshaped flowers in May. 2 to $3 \mathrm{ft} .35 \mathrm{c}$. ea.

ST. JOHN'S WORT, Golden. Hypericum aurea. An effective shrub, having showy single flowers, nearly 2 inches across, that are a brilliant golden yellow. Heavy, $3 \mathrm{ft}$. $35 \mathrm{cts}$. each, \$3 for IO; 2 to $3 \mathrm{ft}$. $25 \mathrm{c}$. each, $\$ 2.25$ for IO.

Prolificum. A strong, hardy shrub; blooms regularly and profusely. 2 to $3 \mathrm{ft} .25 \mathrm{cts}$. each, $\$ 2.25$ for 10 .

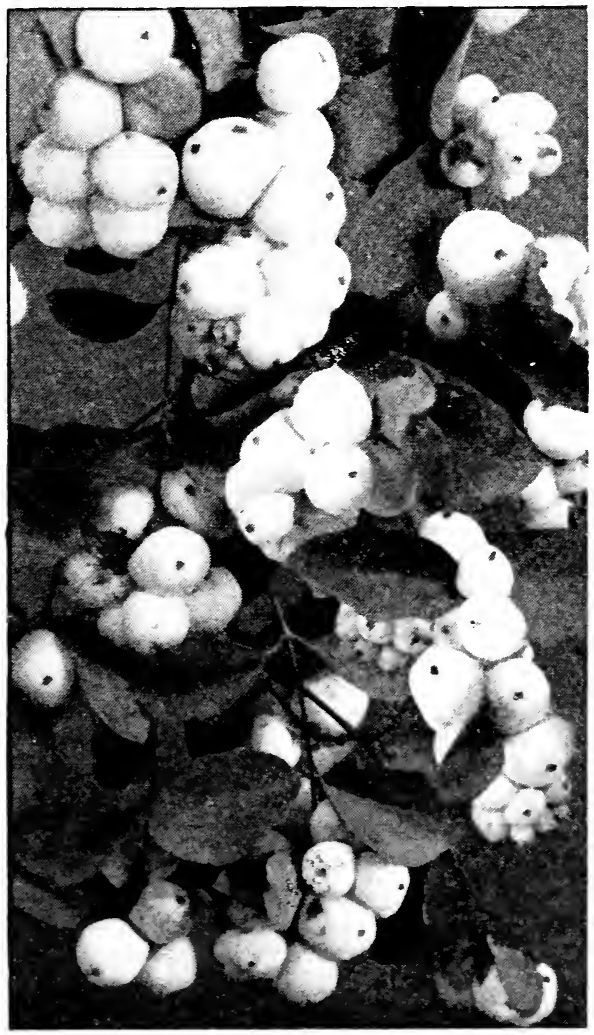

White Snowberry 
SUMACH, Fragrant. Rhus aromatica. A low native shrub, exhaling a strong odor when crushed. Flowers yellow; leaves turning red and yellow in autumn. $2 \mathrm{ft} .35 \mathrm{cts}$. each, $\$ 3$ for Io; I 8 to 24 in. 25 cts. each, $\$ 2.25$ for ro.

Dwarf or Shining. R. copallina. Noted for its shining green foliage, changing to rich crimson in fall. Greenish yellow flowers in August followed by fruit lasting all winter. 2 to $3 \mathrm{ft}$. 25 cts. each, $\$ 2.25$ for 10 .

Smooth. $R$. glabra. Prominent crimson fruit; foliage very effective in fall. 4 to $5 \mathrm{ft}$. $35 \mathrm{cts}$. each, $\$ 3$ for ro.

PURPLE FRINGE, or Smoke Tree. Rhus cotinus. A handsome small tree with distinctive round foliage and brown bark. The odd flowers are purple and carried on long stems. 2 to $3 \mathrm{ft} .35 \mathrm{c}$. ea.

SWEET PEPPER BUSH. Clethra alnifolia. Spikes of clear white, fragrant flowers in August. Does well in shade. I 8 to 24 in. $25 \mathrm{cts}$. each, $\$ 2.25$ for $\mathrm{ro}$.

SYRINGA, or MOCK ORANGE

Golden-leaved. Philadelphus foliis aureis. A low-growing shrub of vigorous habit, very hardy, with golden yellow leaves, which retain their color the entire season. 12 to 18 in. 25 c. ea., $\$ 2.25$ for 10 .

Mock Orange or Common. P. coronarius. One of the earliest to bloom; flowers creamy white, delightfully scented. 4 to $5 \mathrm{ft}$. $35 \mathrm{cts}$. each, $\$ 3$ for I0; 3 tc $4 \mathrm{ft}$. 25 cts. each, $\$ 2.25$ for ro.

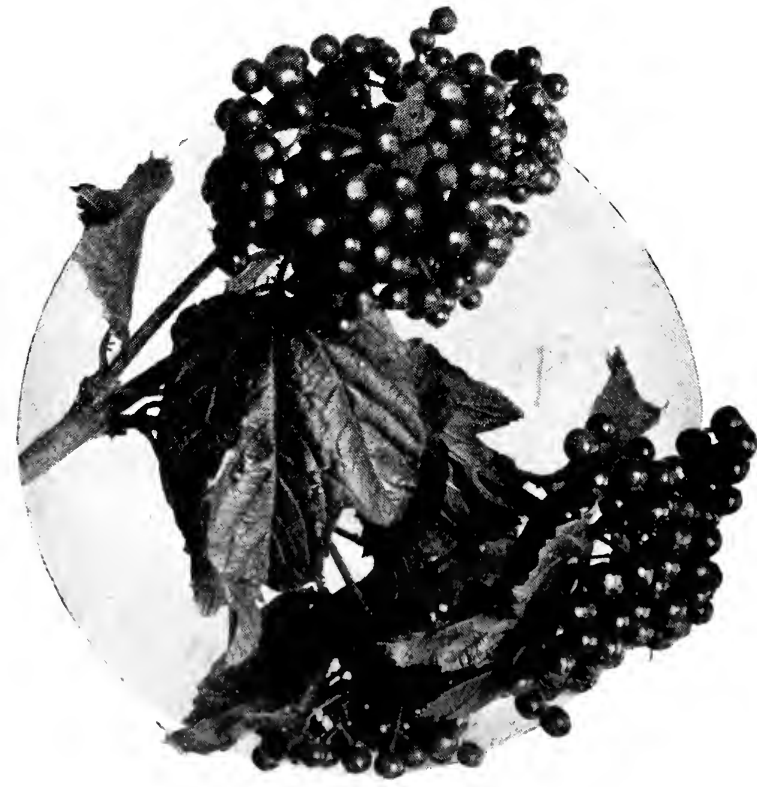

Fruit of Viburnum Opulus
Large-flowered. Philadelphus grandiflorus. Showy, large, white flowers, much later than the common Mock Orange and only slightly fragrant. A tall shrub. 4 to $5 \mathrm{ft}$. 35 cts. each, $\$ 3$ for $10 ; 3$ to $4 \mathrm{ft}$. 25 cts. each, $\$ 2.25$ for 10 .

TAMARISK. Tamarix gallica. A small tree, with slender, spreading branches. Leaves small and heath-like, dull green; flowers delicate, small, pinkish. Valuable for seaside planting. Rather tender in the North. 2 to $3 \mathrm{ft} .25 \mathrm{c}$. each, $\$ 2.25$ for 10 .

\section{VIBURNUM}

The Viburnums are among our best shrubs. The plants are usually of good size, very hardy and of good habit. Flowers are handsome, appear in summer, and are followed by showy fruit.

Maple-leaved. Viburnum acerifolium. Attains about 5 feet in height; branches slender, leaves well formed and long; flowers yellowish white, in May and June; fruit almost black. Does well in shade. 2 to $3 \mathrm{ft}$. $35 \mathrm{cts}$. each, $\$ 3$ for $r o$.

Withe-Rod. $V$. cassinioides. Flat heads of white flowers. Berries green, red and dark purple in clusters in August and September. Foliage bright green and glossy. $3 \mathrm{ft}$. $35 \mathrm{cts}$. each, $\$ 3$ for $10 ; 2$ to $3 \mathrm{ft} .25 \mathrm{cts}$. each, $\$ 2.25$ for Io.

Dentated-leaved. $V$. dentatum. A fine bush for massing if foliage effect is desired. Flowers greenish white; fruit a dark, metallic purple. 3 to $4 \mathrm{ft} .35 \mathrm{cts}$. each, $\$ 3$ for Io; 2 to $3 \mathrm{ft}$. $25 \mathrm{cts}$. each, $\$ 2.25$ for Io.

Wayfaring Tree. V. Lantana. Sturdy shrub or small tree of vigorous habit; soft, heavy foliage; glorious clusters of white flowers in May. 3 to $4 \mathrm{ft} .35 \mathrm{cts}$. each, $\$ 3$ for 10 .

High Bush Cranberry. V. opulus. Attains 8 to Io feet in height, spreading and hardy; has broad, green leaves, showy white flowers and bright red fruit resembling cranberries, which cling until frost-killed. 2 to $3 \mathrm{ft} .25 \mathrm{c}$. each, $\$ 2.25$ for IO.

Snowball, or Guelder Rose. $V$. Opuluis sterile. A favorite shrub; sturdy and requires little care; large, globe-like clusters of pure white flowers in May. 4 to $5 \mathrm{ft}$. $35 \mathrm{cts}$. each, $\$ 3$ for 10 ; 2 to $3 \mathrm{ft}$. 25 cts. each, $\$ 2.25$ for Io.

Japan Snowball. $V$. plicatum. Of medium growth; good foliage and habits, and numerous globular heads of white flowers. 2 to $3 \mathrm{ft}$. $50 \mathrm{cts}$. each, $\$ 4.50$ for 10 . 


\section{VIBURNUM, continued}

Pubescens. Compact habit, slender branches, fine foliage; fruit oval-shaped, slightly flattened, almost black. I 8 to 24 in. 25 cts. each, $\$ 2.25$ for Io.

Plum-leaved. V. prunifolium. A small tree, with smooth, resplendent foliage; white flowers appearing in May and June. 2 to $3 \mathrm{ft}$. $40 \mathrm{cts}$. each, $\$ 3$ for Io.

Single Japanese. $V$. tomentosum. Perfectly hardy, vigorous shrub; beautiful white blooms borne in great profusion in early June. 3 to $4 \mathrm{ft}$. 50 cts. each, $\$ 4.50$ for Io; $2 \mathrm{ft}$. 35 cts. each, $\$ 3$ for Io.

Venosum. Vigorous shrub, with cymes of white flowers, appearing later than blossoms of other species. Fruit abundant and a favorite with the winter birds. 5 to $6 \mathrm{ft}$. $40 \mathrm{cts}$. each, $\mathrm{S}_{3}$ for Io; 3 to $4 \mathrm{ft}$. $35 \mathrm{cts}$. each, \$2.50 for Io.

\section{Climbing and}

AKEBIA quinata. A quaint Japanese climber, with fine foliage, purple flowers before the leaves, and sometimes ornamental fruit. 4 yrs. 35 c. ea., $\$ 2.50$ for Io.

BITTERSWEET. Celastrus scandens. Fine foliage; large clusters of orange-crimson berries retained all winter. 2 to $3 \mathrm{ft} .25 \mathrm{cts}$. each, $\$ 2.25$ for Io.

Japanese. C. orbiculatus. Of extremely sturdy growth and very hardy; the flowers are inconspicuous, but the fruit is abundant and lasts well into the winter. 2 to $3 \mathrm{ft} .25 \mathrm{c}$. ea., $\$ 2.25$ for Io.

\section{CLEMATIS}

Japanese Virgin's Bower. Clematis paniculata. The foliage is thick, clean, glossy and handsome; the flowers, the greatest glory of the vine, are small, white, deliciously fragrant and produced in profusion in late summer. 3 yrs. 35 cts. each, $\$ 3$ for $10 ; 2$ yrs. 25 cts. each, $\$ 2.25$ for Io.

Jackmanii. Flowers large, intense violetpurple, with rich, velvety appearance; blooms in July. 2 yrs. 50 cts. each.

Henryi. Big, finely formed, creamy white flowers. Free grower and bloomer. 2 yrs. 50 cts., $\$ 4.50$ for 10.

Gypsy Queen. A free grower, with dark purple flowers. 2 yrs. 50 cts. each.

Virginiana. Extremely rapid grower; bears quantities of white blossoms in summer, followed by hair-like seedplumes. 4 yrs. 50 cts. each, $\$ 4.50$ for Io.

DUTCHMAN'S PIPE. A ristolochia Sipho. Magnificent green foliage, and curious pipe-shaped, yellowish brown flowers. 2 to $3 \mathrm{ft}$. $50 \mathrm{cts}$. each, $\$ 4$ for Io.
WEIGELA, Rose-colored. Diervilla rosea. A symmetrical-growing shrub, with good foliage; some flowers are delicate pink, others rose, a few almost white. 3 to $4 \mathrm{ft}$. $25 \mathrm{cts}$. each, $\$ 2.25$ for Io.

Variegated-leaved. D. rosea variegata. Leaves silvery and variegated: flowers pink. 3 to $4 \mathrm{ft} .25 \mathrm{c}$. ea., $\$ 2.25$ for 10.

Eva Rathke. One of the best hybrids, and a heavy bloomer with red flowers. 2 to $3 \mathrm{ft}$. 25 cts. each, S2.25 for Io.

WITCH-HAZEL. Hamamelis Virginiana. Narrow, bright yellow flowers on almost bare branches in October and November Leaves bright yellow in autumn. 3 to 4 ft. $35 \mathrm{cts}$. each, $\$_{3}$ for I0; 2 to $3 \mathrm{ft}$. 25 cts. each, \$2.25 for Io.

YELLOW ROOT. Xanthorrhiza apiifolia. Low shrub, with particularly handsome foliage. $20 \mathrm{cts}$. each, Si.50 for Io.

\section{Trailing Vines}

EUONYMUS, Creeping. Euonymus radicans. Evergreen vine; clings to a wall like Ivy; grows 8 to io feet high. 2 yrs. 25 cts. each, $\$ 2.25$ for Io.

HONEYSUCKLE, Scarlet Trumpet. Lonicera sempervirens. Bears large clusters of scarlet, tubular flowers. Strong plants $25 \mathrm{c}$. each, $\$ 2.25$ for Io.

Sullivant's. L. Sullivantii. Leaves of a peculiar silver-blue; flowers pale yellow, marked purple; berries scarlet. Strong plants, $25 \mathrm{c}$. each, \$2.25 for Io.

Hall's Japanese. L. Halliana. Sturdy; almost evergreen; flowers pure white, changing to yellow, deliciously fragrant; blooms July to December. 25 cts. each, $\$ 2.25$ for 10 .

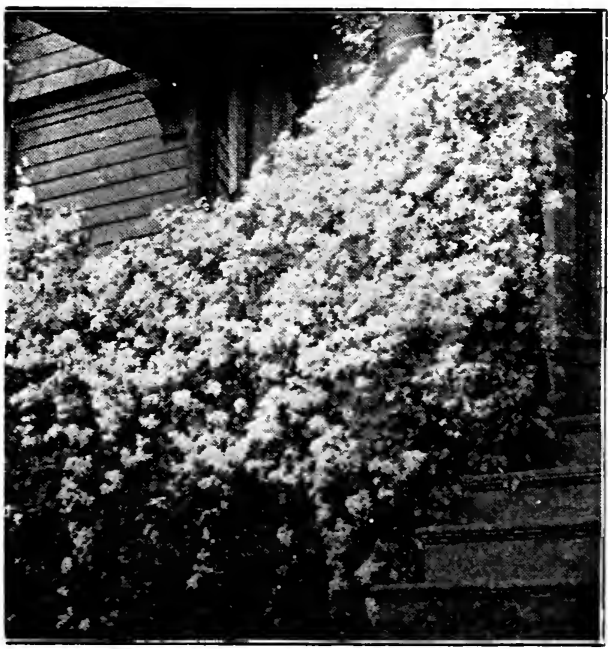

Clematis paniculata 


\section{CLIMBING AND TRAILING VINES, continued}

IVY, American, or Virginia Creeper. Ampelopsis quinquefolia. This climber covers walls, verandas, etc., very quickly. Beautiful, compound foliage, intense crimson in autumn. 4 yrs. 25 cts. each, $\$ 2.25$ for $\mathrm{x} 0$.

Engelmann's. A. Engelmanni. A variety of the above, with better power to cling to walls or tree-trunks; often grows to Io feet in a season. 2 yrs. 25 cts. each, $\$ 2.25$ for Io.

Boston. A. Veitchii. Rapid grower, and clings with great tenacity to brick and stone structures. Foliage is exquisite, the thick, compact, bright leaves overlapping and covering the supporting object. 3 yrs. 25 cts., $\$ 2.25$ for Io.

English. Hedera Helix. Makes excellent edging for flower-beds. Its normal use is for covering walls, etc., but this is hardly possible in the North where it needs protection. 35c. each.

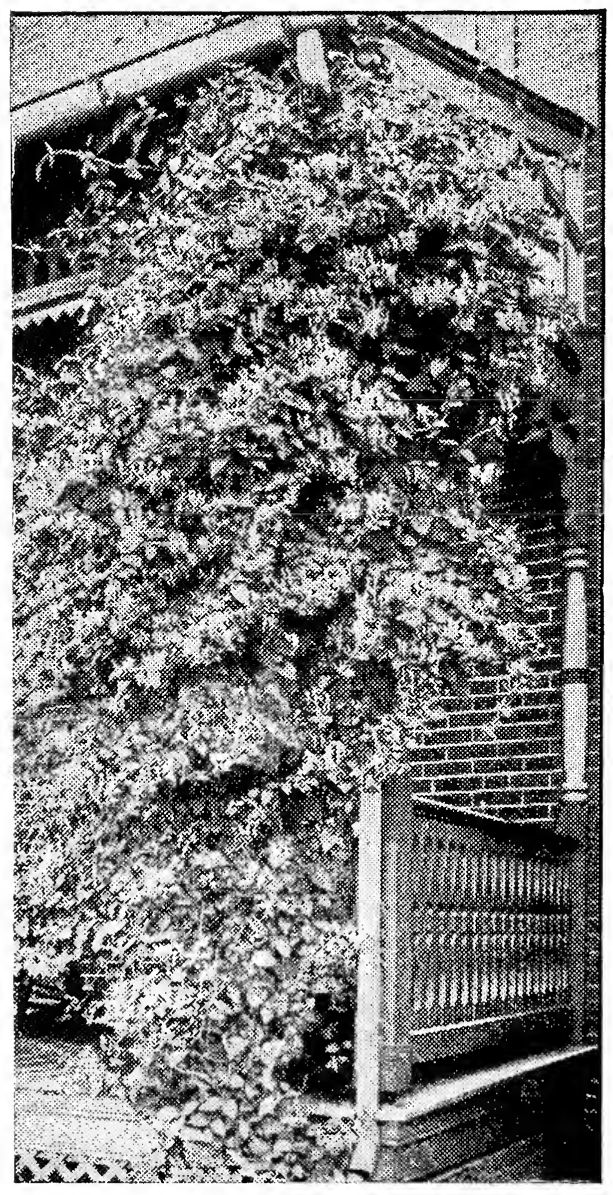

Hall's Japanese Honeysuckle (see page I7)
KUDZU VINE. Pueraria Thunbergiana. A vigorous vine, often producing stems 30 to 40 feet in a season. Dies down in winter in the northern states. Plants 25 cts. each, $\$ 2.25$ for $x 0$.

MATRIMONY VINE. Lycium vulgare. Very long branches, slightly thorny; good foliage and flowers. 24 in. $25 \mathrm{cts}$. each, $\$ 2.25$ for 10 .

MYRTLE, or Periwinkle. Vinca minor. A splendid plant for covering the ground; leaves glossy green, edged with white; single blue flowers. I 5 cts. each, $\$$ I for Io, $\$ 8$ per Ioo.

Single Purple. V. minor, var. Purple flowers. I5 cts. each, \$I for Io, $\$ 8$ per Ioo.

Double Blue. $V$. minor carulea $f$. pl. Double blue flowers. I 5 cts. each, \$I for Io, $\$ 8$ per Ioo.

SILK VINE. Periploca graca. Leaves glossy, dark green; flowers in loose clusters, brownish purple, greenish at margins. Strong plants 25 cts. each, $\$ 2.25$ for IO.

SILVER VINE. Actinidia arguta. A sturdy, healthy climber, with dark green, glossy, heart-shaped leaves; white, purple-centered flowers, succeeded by round, edible, fine-flavored fruit. 4 yrs. 50 cts. each, $\$ 4$ for 10.

TRUMPET VINE. Bignonia radicans. Sturdy, woody vine; leaves light green; clusters of orange-scarlet flowers in July and August. 3 yrs. 25c. ea., $\$ 2.25$ for ro.

VITIS heterophylla. A grape-like vine, which makes strong growth, particularly when severely cut back in early spring. The charm of the vine is the fruit, which begins to color in late August and September, giving clusters of berries of different porcelain-blue shades. Quite unique. 3 yrs. 25 cts. each, $\$ 2.25$ for Io.

WISTARIA, Japanese. Wistaria multijuga. Rapid-growing, climbing plant, with long cluster of blue flowers. $50 \mathrm{cts}$. each.

White Japanese. $W$. multijuga alba. Same as the preceding, with white flowers. Both of these are strong growers and much more certain to bloom than the Chinese Wistaria. 50 cts. each.

Chinese. W. Sinensis. A vine of rapid growth, soon attaining great size. Clusters of pale blue flowers in May and June. 50 cts. each.

White Chinese. $W$. sinensis alba. White flowers; otherwise the same as the blue form. 50 cts. each. 


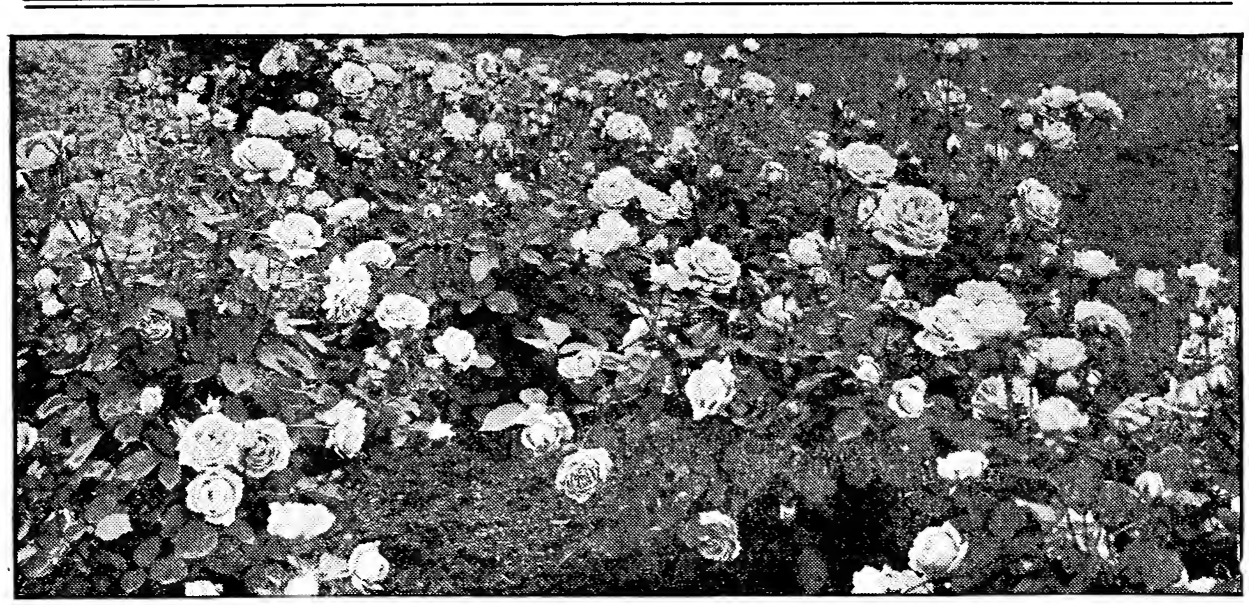

One cannot imagine a New England garden without Roses

\section{ROSES}

Meadow. Rosa blanda. Just right for the shrubbery border. Flowers pink, more than 2 inches in diameter, showy and fragrant, appearing May and June. 24 to 30 in. 25 cts. each, $\$ 2.25$ for Io, \$I5 per IOO; I 8 to 20 in. 20 cts. each, $\$ \mathrm{I} .75$ for IO, \$I2 per Ioo.

Swamp. $R$. carolina. A very good Rose for low ground or water-sides. Growth upright, with slender branches; flowers are large, pink, borne in clusters from June until August. Red twigs in winter. I 8 to 24 in. 20 cts. each, \$I.75 for IO, \$I 2 per IOo.

Dwarf Wild. $R$. lucida. Does well everywhere. Foliage is shining; blossoms gay and attractive, bright pink followed by abundant pips which, with the red twigs, make the plant interesting in winter. I 8 to 24 in. 25 c. ea., $\$ 2.25$ for Io.

Japanese Climbing. $R$. multiflora japonica. Branches long and arching, covered with great, pyramidal clusters of small, pure white flowers. The plant is vigorous, hardy and of climbing habit. Has abundant fruit. 2 to $3 \mathrm{ft}$. $25 \mathrm{cts}$. each, $\$ 2.25$ for Io.

Nitida. A low plant, with shining, bright green leaves and single pink flowers. I 8 to 24 in. 25 cts. each, $\$ 2.25$ for Io, $\$$ I5 per Ioo.

Sweetbrier. R. rubiginosa. A handsome, hardy Rose of good habit; foliage bright green and fragrant; flowers of fair size, bright pink. Blooms in June. 3 to $4 \mathrm{ft}$. 35 cts. each, $\$ 2.50$ for Io.

Rugosa. A single Rose, particularly good for shrubberies. The foliage is dark green, wrinkled and shining; the rosy carmine flowers are large and attractive. The fruit is bright red, very ornamental, and remains on the plant all winter. 2 to $3 \mathrm{ft}$. $25 \mathrm{c}$. each, $\$ 2.25$ for Io.
Rugosa alba. Like $R$. rugosa, but of lesser growth. Flowers are pure white. 2 to $3 \mathrm{ft}$. $25 \mathrm{cts}$. each, $\$ 2.25$ for Io.

Madame Georges Bruant. A variety of R. rugosa. Flowers large, semi-double, growing in clusters and flowering freely in late summer. The buds are exquisitely formed and delightfully fragrant. I 8 to 24 in. $25 \mathrm{cts}$. each, $\$ 2.25$ for Io.

Rubrifolia. Tall, upright grower; foliage red, turning bluish gray later; flower pink, in June. 2 to $3 \mathrm{ft}$. $35 \mathrm{cts}$. each.

Prairie. $R$. setigera. Plants grow to $6 \mathrm{feet}$ or over, having long, slender, recurving branches; flowers are a deep rose-color, turning lighter as they fade and are produced in many clusters in early July. 2 to $3 \mathrm{ft} .25 \mathrm{cts}$. each. $\$ 2.25$ for Io.

Scotch. R. spinosissima. The blossoms, opening in May and June, are single, closely arranged on the stem, and are white, light pink or yellowish. I2 to I 8 in. 35 cts. each.

\section{MOSS ROSES}

Crimson Globe. Like all Moss Roses the buds, leaves and stems are covered with an abundance of deep green moss. Flowers are double and globular; beautifully mossed, very fragrant and crimson. The plant is a hardy and vigorous grower. $35 \mathrm{cts}$. each.

Henri Martin. Deep rosy carmine shaded to bright crimson. $35 \mathrm{cts}$. each.

Salet. One of the oldest and best of its class, and is quite popular. Flowers are rosy pink, full and large. Buds and blossoms fully mossed. $35 \mathrm{cts}$. each.

Blanche Moreau. Flowers pure white, of perfect form, large and rich; well furnished with deep green moss. 35 cts. each. 


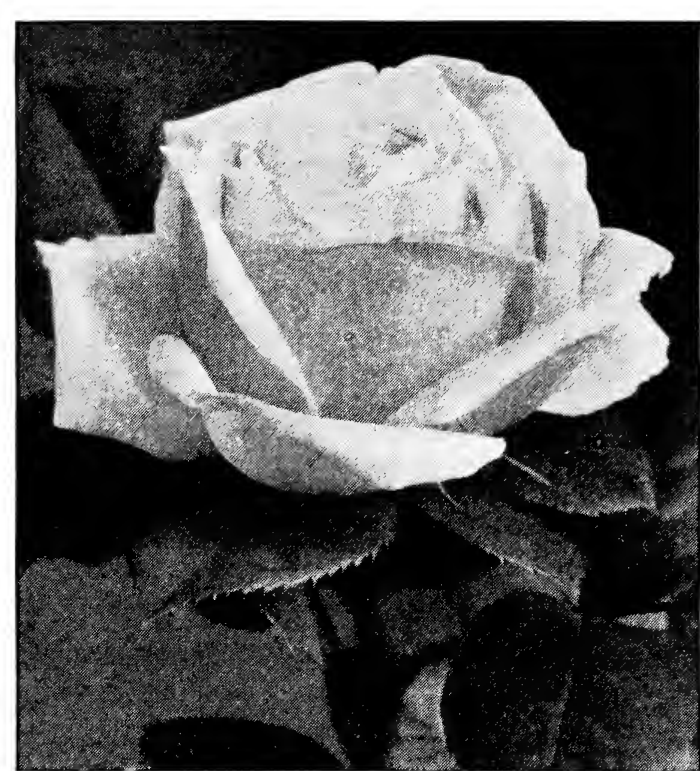

Frau Karl Druschki Rose

\section{HARDY HYBRID PERPETUAL ROSES}

In all these varieties, we offer wellestablished, field-grown plants. Plant deep in well-enriched soil.

35 cts. each, $\$ 3$ for $10, \$ 20$ per 100 , except as noted

Alfred Colomb. Blossoms are exceedingly perfect, extra large and round, and very fragrant; in color clear cherryred, passing to bright, rich crimson.

American Beauty. Without doubt, the most popular Rose in this country and deservedly so. The bush has a quick, healthy, sturdy growth, the stems are long and straight, and the foliage is superb. The flowers, which are immense in size and globular in form, have a very bold, exquisite fragrance, which is not oppressive. Color shades from a deep pink to carmine-cerise. $40 \mathrm{cts}$. each.

Anna de Diesbach (Glory of Paris). A Rose which blooms over a long period, and whose flowers are particularly good on account of lasting color and fragrance. Vigorous grower and profuse bloomer. Blossoms double, well formed and in color a brilliant carmine.

Baron Rothschild. A magnificent Rose. The blooms are symmetrical, large and of a delicate pink.

Capt. Christy. Exceedingly desirable, as it is very nearly everblooming. Flowers large, double, delicate pink, deepening at center to rosy crimson.

Fisher Holmes. Rich scarlet-crimson; flowers large, and borne in abundance.
Frau Karl Druschki. This Rose, without doubt the finest white Rose in cultivation, is excellent both for cutting and for the gardens; clear white and well formed.

Gen. Jacqueminot. One of the best-known and most popular Roses in cultivation. Flowers bright, rich, velvety crimson, and almost unequaled in beauty.

Gloire Lyonnaise. The color of this Rose, which is a pale lemon, is nearest to true yellow of any Hybrid Perpetual. The bush is sturdy, upright and almost without thorns.

John Hopper. Large, regular flowers; a brilliant rose, shaded with crimson; splendid bloomer.

La France. A very popular Rose. The blooms are fine peach-color, delicately shaded with rosy flesh; blooms early and long.

Mad. Gabrielle Luizet. Has big beautiful flowers, whose petals have a peculiar, satiny appearance; the color is a bewitching tone of clear coral-rose, delicately blended with lavender and pearl.

Magna Charta. A hardy, healthy Rose, long holding high favor as a grand garden variety; deep, rich pink.

Margaret Dickson. This splendid variety is a strong grower and good bloomer; the flower, a pure, waxy unblemished white has grace and charm.

Marshall P. Wilder. Dark, deep red.

Mrs. Charles Wood. Flowers appear early and continue all through the season; bright, fiery scarlet passing to rosy crimson, shaded with maroon.

Mrs. John Laing. Very popular; has fine foliage; flowers are a soft rosy pink.

Mrs. R. G. Sharman-Crawford. Given a gold medal by the National Rose Society. Deep rosy pink, outer petals pale blush, base of petals white; blooms are large and perfect.

Paul Neyron. Flowers extra large, sometimes 5 inches in diameter; strong, clear, deep rose. Foliage beautiful, shining green; plant a strong grower.

Prince Camille de Rohan. Deep, velvety crimson, blended with maroon and black; flowers produced with great freedom. Should be in every garden.

Ulrich Brunner. A splendid Rose for mass planting; hardy and vigorous. Flower highly fragrant, full and globular a fine crimson toned with scarlet.

Mad. Plantier. Pure white; very hardy. One of the best Roses in cultivation and highly recommended for cemetery planting. 25 cts. each. 


\section{HYBRID TEA ROSES}

Gruss an Teplitz. Dark crimson, passing to fiery red. The flowers are fragrant and abundant. It blooms all summer and is particularly good in September.

Kaiserin Augusta Victoria. A Rose of great merit and very popular. Flowers freely and continuously from early spring until late fall. Delicate creamy white, with delicious fragrance. $50 \mathrm{cts}$.

Killarney. Deep shell-pink; flowers large, with petals very deep; free-flowering and very hardy. $40 \mathrm{cts}$. each.

Mad. Caroline Testout. Flowers are big and round, in large clusters; salmonrose edged in violet-carmine; quite fragrant. Grows strongly and flowers freely. 40 cts. each.

Marchioness of Londonderry. Ivorycolor; shell-shaped petals. Large flowers. 40 cts. each.

White La France. A well-formed, finely perfumed Rose; silvery white, with just a faint touch of rose-blush on its satiny petals. 50 cts. each.

Harrison's Yellow. A semi-double yellow Rose and quite popular. Exceptionally hardy and vigorous. 35c. each.

Persian Yellow. A bright yellow Rose, one of the standards of this color; forms a very vigorous bush. $40 \mathrm{cts}$. each.

Soleil d'Or. Golden yellow, tinged with orange and crimson; a large Rose and strong grower; very sweet. $40 \mathrm{cts}$. each.

\section{CLIMBING ROSES}

Dorothy Perkins. This is a vigorous, sturdy climber, withstanding extreme cold. The flowers are shell-pink, produced in large clusters of thirty to forty, and are well adapted for cutting and decorating.

Dawson. Bright carmine; very double and produced in large, pyramidal clusters; blooms in June much earlier than the Ramblers, and is a great acquisition.

Farquhar. Bright, shining green foliage; bears splendid clusters of bright pink, double flowers.

Lady Gay. A good grower, unsurpassed for covering trellises, arbors, fences and buildings. Flowers of a delicate cherry-pink, fading to white; leaves a dark, glossy green. Clusters large, composed of from fifty to a hundred blooms, covering the plant very closely.
Prairie Queen. Bright rosy red; clusters of compact, large, double flowers.

Seven Sisters. An old-fashioned Rose, but by some considered desirable.

Memorial. Rosa Wichuraiana. Grows strongly in almost any soil, in sun or shade; large, single blossoms; pure satiny white with golden stamens.

Baltimore Belle. Pale blush-white blossoms in clusters; very double.

Crimson Rambler. The first-known Rambler and a general favorite. The plants are strong climbers, sometimes reaching $\mathrm{I} 5$ to 20 feet in a season. The flowers, produced in magnificent clusters, are a brilliant crimson.

Setigera-Wichuraiana. A hybrid of the two species, retaining the good foliage and trailing habit of the latter, with the large, single, beautiful shell-pink flowers of the former.

Excelsa. One of Walsh's best ramblers, blooming in July. Much finer than the Crimson Rambler which it quite resembles in color but blooms much later.

W. C. Egan. One of Dawson's best productions. The color is blush-white, resembling the Souv. de la Malmaison; free grower and very hardy; blooms in June.

All the Climbing Roses, 2 to 3 ft., 25 cts. each, $\$ 2.25$ for 10
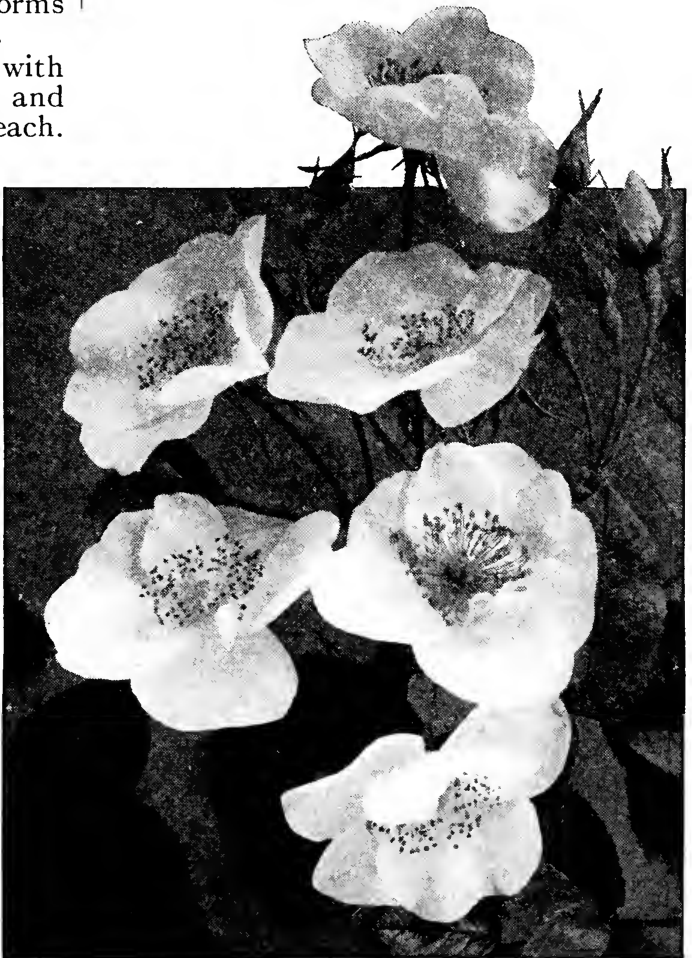

Single Roses 


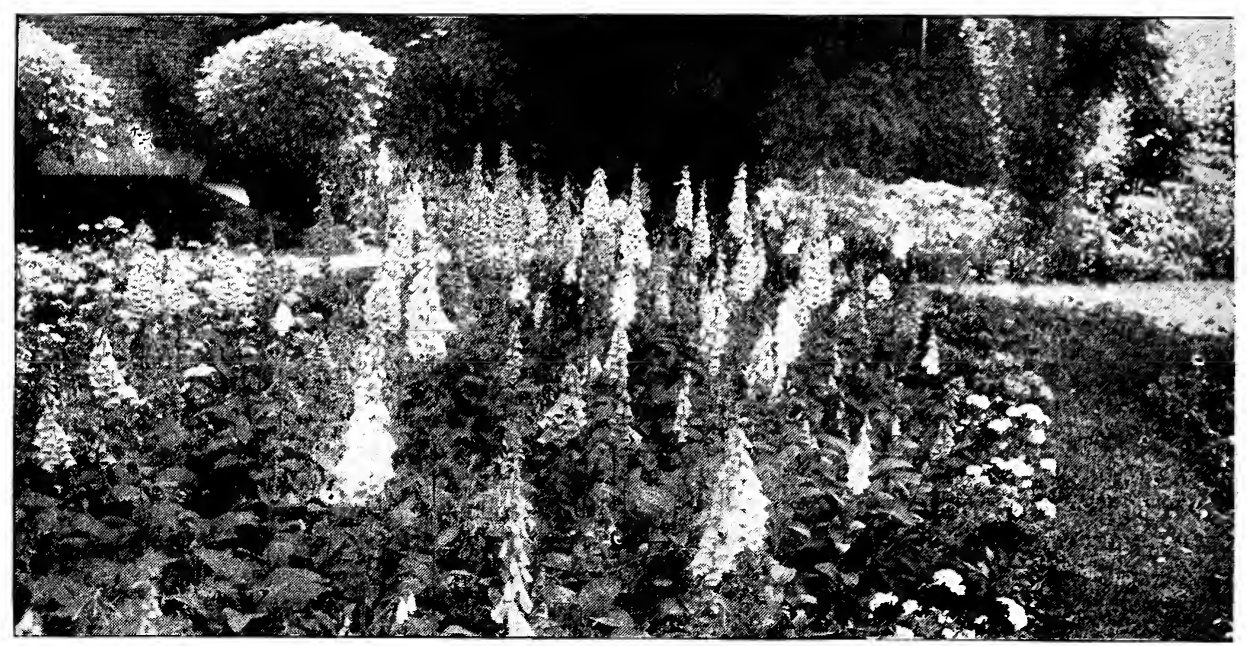

A planting of Foxgloves (see page 24)

\section{Hardy Herbaceous Perennials}

Hardy Perennials are rapidly taking the place of annuals, as they need not be renewed each season. The plants should bloom the first year after planting; this fact makes them particularly valuable, as they will give immediate effects in the garden. With the exception of the Peonies, all may be set in the spring-it is usually considered better practice to set Peonies in the fall, although spring planting is successful. The varieties in this list are our own selection from the multitude of sorts on the market, and we believe them to be the most useful and desirable.

Price of all plants, unless exceptions are noted, 15 cts. each, $\$ 1.25$ for $10, \$ 5$ for 50 , $\$ 10$ per 100

ACHILlEA, The Pearl. Achillea ptarmicoides. A comparatively new variety. Flowers large, clear white and fulldouble; probably the best plant of the whole family.

AGROSTEMMA coronaria. Flowers rosy crimson, almost an inch and a half across; deep flush at throat; borne on tips of branches from I to 2 feet tall. A splendid border plant.

ALYSSUM saxatile, Gold Dust. A mass of golden yellow flowers makes this lowgrowing plant look like a sheet of gold. A rapid grower, producing hundreds of little flower-heads in early spring.

ANEMONE Japonica rosea elegans. Beautiful flowers $21 / 2$ inches or more in diameter; pinkish rose. September.

Honorine Joubert. Flowers are borne on long stems and are clear white, with golden yellow center. September to November.

Pennsylvanicum. Flowers are clear white and open in June. A native and succeeds almost everywhere.

ANTHEMIS tinctoria. The large, bright golden yellow flowers are produced in summer. Foliage finely cut, and the plants succeed in the poorest soil.
ANTHERICUM liliastrum (St. Bruno's Lily). The plants grow about 2 feet high, and the fragrant white blooms are produced in May and June.

AQUILEGIA canadensis. The common field Columbine. The flowers are yellow, orange and red, and are borne in April and May.

Chrysantha. The Golden Spurred Columbine. Plants are 3 to 4 feet high, bearing flowers that vary in color from light primrose to canary-yellow, with long spurs.

Cærulea. The Rocky Mountain Columbine. The blue sepals and white petals are widely spread, forming a flower about 2 inches across. The plant grows from 12 to 18 inches in height, and blooms from May to June.

Hybrids. A. chrysantha and carulea intercrossed. These are excellent, with flowers of brilliant colors and extra-long spurs.

ARABIS alpina. Rock Cress. An evergreen creeping plant. Introduced into cultivation from Switzerland. Perfectly hardy and grows almost anywhere. The flowers are clear white, about $3 / 4$ of an inch across, and borne in spring. 
HARDY HERBACEOUS PERENNIALS, continued

ARMERIA maritima. A dwarf plant suitable for edging or borders. The foliage is green the whole year and in summer the plants produce rosy pink flowers on stems nearly 8 inches long.

ARUNDINARIA japonica, or Bambusa Metake. One of the best dwarf Bamboos that is perfectly hardy in northern climates.

ASCLEPIAS tuberosa. Butterfly Weed. This is possibly one of the most delightful of our native plants. The flowers are produced in July and August, and are wonderfully rich orange-red. The plants will grow anywhere and offer great possibilities for massing for color effect.

ASTER novæ-angliæ. Michaelmas Daisy. The violet-purple flowers are borne on stems from 3 to 6 feet in height during the months of September and October; easily grown.

Novæ-angliæ rosea. Similar to the preceding, but with pink flowers.

Mixed. In our fields we are growing quantities of hardy Asters in unnamed varieties. We can furnish these in almost any quantity.

ASTILBE japonica. Perfectly hardy and grows well in any border. The flowers are produced in plumes, a re clear white and come in early summer.

AUBRIETIA deltoidea. A dwarf plant, producing purple flowers in April and May. Foliage in tufts or masses.

BOCCONIA japonica. These plants grow to a height of about 9 feet, producing whitish flowers in large panicles.

BOLTONIA asteroides. The pure white flowers are borne during the late summer on stems from 5 to 7 feet high.

Latisquama. The flowers of this variety are lavender, shaded pink; free bloomer; useful for cut-flowers.

CAMPANULA persicifolia. The foliage of this variety resembles that of the peach. Blue flowers produced in June and July.

White. Similar to the above but with clear white flowers.

Medium. Canterbury Bells. An old-fashioned flower. Our collection includes the double and single varieties, with colors varying from deep and light blue to white and pink.
CHRYSANTHEMUM, Pompon or Button. Hardy garden varieties that come into bloom from October until the plants are killed by heavy frost. Our collection includes the hardiest only in Pink, Red, White, Yellow and Bronze, and can be furnished in separate colors or mixed as desired. 25 cts. each, $\$ 2$ for Io.

CLEMATIS Davidiana. The plants grow from 2 to 3 feet tall; the flowers are blue, produced freely in clustered heads in summer; good foliage.

COREOPSIS grandiflora. The large yellow flowers are borne on stems 2 $\mathrm{ft}$. or more in height; bloom in summer.

Lanceolata. Plant is from I to 2 feet tall; blooms in June, with golden yellow flowers.

DELPHINIUM, Garden Hybrids. Bee Larkspurs. Flowers are different shades of blue, borne in long spikes, on stems 3 to 6 feet in height. Midsummer.

Grandiflorum. Chinese Larkspur. More slender stems, 2 to 3 feet high. Flowers double and single, varying from deep blue to white.

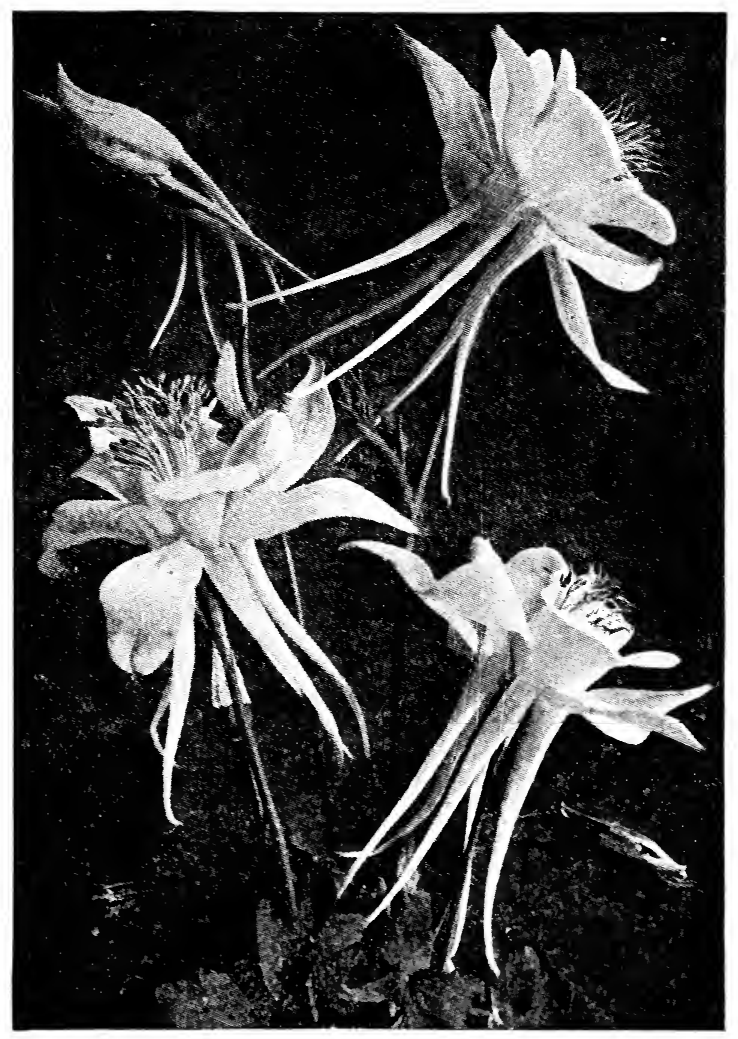

Golden Spurred Columbine (see page 22) 


\section{HARDY HERBACEOUS PERENNIALS, continued}

DIANTHUS barbatus. The old-fashioned and well-known Sweet William. Plants are used for borders and color masses. Flowers come in great profusion in June and July. We offer double and single varieties in many colors.

DICENTRA spectabilis. The old-fashioned Bleeding Heart. Plants from I to 2 feet tall, with long, curved sprays of rose-colored flowers.

DICTAMNUS Fraxinella albus. The Gas Plant. A bushy plant about 3 feet high, with white flowers. After the plants are set in the garden or the border they should not be disturbed.

Rubra. In all respects like the preceding except in color of the flowers, which are a deep red. Both produce flame if a lighted match is thrust in the flower-spike when in full bloom.

DIGITALIS purpurea. Foxglove, or Thimble Flower. The flower-stems grow from 5 to 8 feet tall, bearing quantities of thimble-shaped flowers of white and purple. Our collection includes mixed varieties only.

EPIMEDIUM. Low-growing plants, with quantities of orchid-like flowers in May. The colors are white with pink and yellow shadings. $25 \mathrm{cts}$. each, \$2 for 10.
ERIANTHUS Ravennæ. Beautiful pampas-like grass with purple plumes; grows from 9 to I 2 feet high; fairly hardy. 25 cts. each, $\$ 2$ for Io.

ERIGERON speciosum. Low-growing plants with flower-stems a foot or more in height. Flowers rosy violet; blooms in June and July and again sometimes in the fall. $25 \mathrm{cts}$. each, $\$ 2$ for 10.

EULALIA Japonica. A tall, grass-like plant used for massing or planting as a background for perennials. $25 \mathrm{cts}$. each, $\$ 2$ for IO.

EUPATORIUM ageratoides. Used principally as a border plant in shaded places. Flowers pure white, borne on stems 3 to 4 feet high, during August and September.

FERNS. Our collection includes the most desirable hardy native Ferns. Generally collected plants.

FUNKIA lancifolia. Day Lily. The pale lilac flowers are borne on stems from I to 2 feet high, each stem producing from six to ten blooms. The foliage is long and narrow. We also offer the more common variegated variety.

Ovata. Leaves are much broader and the flowers are a deeper blue. We also have a variety with marbled foliage. Sieboldiana. The metallic blue tinge of the foliage distinguishes this variety from the others. The flowers have slender tubes, and are blue in color. All the above flower in early summer.

Subcordata grandiflora. The flowers are extra large, opening from 4 to 6 inches in length; pure white, with a delightful orange - like odor. August and later. 25 cts. each, \$2 for Io.

GAILLARDIA g randiflora. Plants grow rather straggling but will thrive in almost any sunny place. The flowers vary in color from bright orange through the yellows, reds and browns. Very showy.

GERANIUM sanguin e um lancastriense. The plants are low and spreading, almost trailing, about $\mathrm{I} / 2$ feet high, with bright rose flowers in summer.

GILLENIA trifoliata. Flowers white, with rosy tinge, bellshaped and borne on stems 2 to 3 feet long; excellent for cutting. 


\section{HARDY HERBACEOUS PERENNIALS, continued}

GYPSOPHILA paniculata. Flowers pure white; very small but borne in large clusters. The plants grow from 2 to 3 feet high and are perfectly hardy; fine for arranging with cut-flowers.

HELENIUM autumnale. Sneeze-wort. Almost as showy as the sunflower or rudbeckias. The plants may be used as screens, as they grow from 4 to 6 feet in height. The flowers are produced freely during the early autumn.

HELIANTHUS grandiflora. The plants of this variety seldom exceed 4 feet in height. The flowers are large, with bright yellow rays and a yellow disc which turns brown as the petals fade. Both the single and double varieties are offered.

Maximilianus. Flowers brilliant golden yellow and come in October; plants 8 to ro feet tall, if well grown.

Mollis. Flowers light yellow; foliage downy white; plants from 3 to 4 feet tall; blooms in midsummer.

Miss Mellish. Golden yellow, single flowers produced freely in September and early October; one of the best and most dependable Sunflowers.

Orgyalis. The tallest of the family, plants often reaching Io feet in height; flowers are pale lemon-yellow and abundant in September and October.
HOLLYHOCK, Chater's Best Strain. Choice colors-Red, Yellow, Pink and White; extra fine; double. We also offer excellent single varieties. All are good summer bloomers, growing from 4 to 6 feet or more in height.

IBERIS gibraltica. Evergreen plant suitable for edgings or rockeries Flowers white, sometimes with purple tinge.

Sempervirens. Much like the above, and called the hardy Candytuft. The flowers are pure white and borne very profusely in April and May.

IRIS cristata. A dwarf variety of the Iris, with light blue flowers and with segments tinted yellow.

Germanica. The well-known German Iris. One of the best garden plants; usually several flowers to the stem. which may vary from I to 2 feet high according to soil and climate. TVe offer a large assortment of unnamed varieties in separate colors. All strong, well-grown plants.

Japan, or Kæmpfer's. These can be planted in autumn or spring. We offer a fine collection of unnamed sorts in separate colors.

Pseudacorus. The wild European Iris. Flowers bright yellow, on stems 3 feet tall; likes damp soil.

\section{HEMEROCALLIS Dumor-} tieri. Earlier than other varieties of Hemerocallis. Flower-stems from I $1 / 2$ to 2 feet high, producing orangeyellow blooms.

Flava. This variety blooms in June and is one of the most delightful of all the hardy flowers; clear lemonyellow; excellent for planting with the large blue German irises.

Fulva. Blooms in summer; the orange-yellow blossoms are borne on stems from 3 to 4 feet long, good for naturalization. \$6 per Ioo.

Thunbergii. Very similar to $H$. flava, but the flowers are ten days later and have no fragrance.

HIBISCUS Moscheutos. Rose Mallow. Choice plants for masses, blooming for a long period in midsummer, flowers varying in color from white to rose, often 5 to 8 inches across, and borne on stems 3 to 5 feet high.

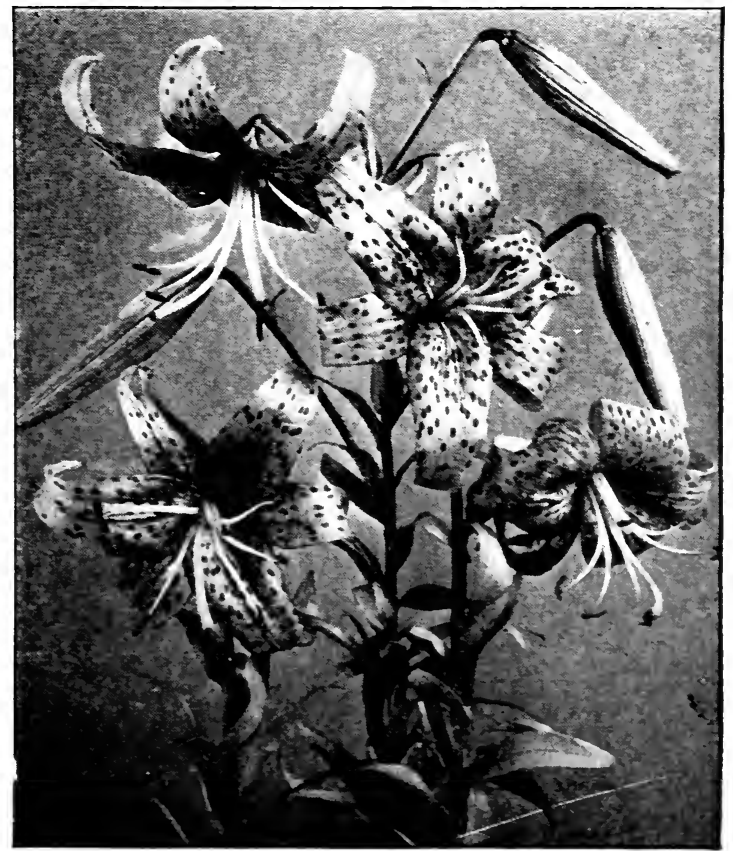

Lilium tigrinum (see page 26) 


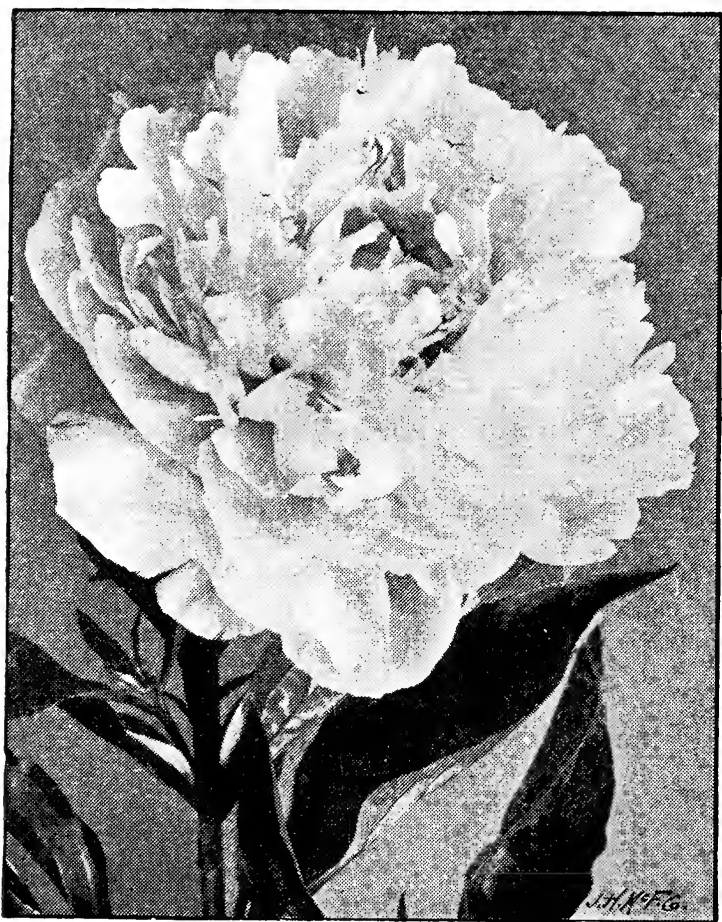

Herbaceous Peony (see page 27)
HARDY HERBACEOUS PERENNIALS, con.

Iris sibirica. Narrow foliage, tall stems, and flowers in many shades of blue with white markings.

Versicolor. The common Blue Flag. Flowers violet-blue, veined with purple; borne on stems from I to 3 feet high; a good water plant.

LATHYRUS latifolius. Perennial Pea. A vigorous climber that reaches a height of 4 to 6 feet. Foliage is similar to that of the sweet pea. The flowers are large but have no odor, and are borne in numerous clusters. We offer two varieties-Rose and White.

LIATRIS pycnostachya. Kansas Gay Feather. A strikingly odd and beautiful plant. Tall stems appear in August and September with densely flowered, rosy purple spikes, 5 to I 8 inches long. $25 \mathrm{cts}$. each, $\$ 2$ for ro.

Scariosa. Flowers of this species are deep purple, and borne on stems from 3 to 4 feet tall. Both do well in poor soil.

\section{LILIES}

25 cts. each, $\$ 2$ for 10

Auratum. Gold-banded Lily. One of the most beautiful of the hardy Lilies. The flowers are ivory-white, marked with a yellow band and crimson dots.
LILIES, continued

Candidum. Ascension Lily. Flower-stems are 3 to 4 feet high, and produce a number of pure white, bell-shaped blossoms, which are from 4 to 5 inches long, in early July; one of the best Lilies and easily grown.

Speciosum album. The flowers are pure white, delicately fragrant, and borne on stems from 2 to 4 feet in length.

Speciosum roseum. Similar to the preceding, but with rose-colored flowers.

Tigrinum. The old familiar Tiger Lily. Flowers orange, with black spots; stems 3 to 6 feet high. Easily grown.

Umbellatum. A variety from Japan, with one to five flowers on a stem 2 feet tall; selfcolored in yellow and orangered; blooms in June and July.

LILY-OF-THE-VALLEY.This well-known plant grows freely in rich soil and cool places. The bell-shaped, white flowers are borne in early spring and are very fragrant. \$I for IO, $\$ 5$ per roo.

LOBELIA cardinalis. Cardinal Flower. Although a bog plant, this is of easy cultivation in gardens, where it blooms all summer. It is much used now for its color effect. The flowers are rich, intense red.

LUPINUS polyphyllus. Hardy Lupin. The deep blue flowers are something like those of the wistaria, and are produced during June and July. Plants grow 2 to 5 feet high.

LYCHNIS chalcedonica. London Pride. Flowers are brilliant scarlet, and come in July and August on plants from 2 to 3 feet high.

LYSIMACHIA clethroides. Flowers are clear white and produced in summer on long stems; particularly valuable for cutting; plantś grow from 2 to 3 feet tall. The foliage turns a good yellow in autumn.

Nummularia. Moneywort. A creeping plant that grows particularly well in shaded places; blooms profusely, bearing small, golden yellow blossoms.

MERTENSIA virginica. One of the best early flowers, blooming in April and May. The color is a porcelain-blue turning pink. It loses its foliage in summer. 


\section{HARDY HERBACEOUS PERENNIALS, continued}

MITCHELLA repens. Partridge Berry. An evergreen plant, with shining foliage and bright red berries which remain on all winter. Useful for shaded places.

MONARDA didyma. The Indian name of "Flaming Flower" well describes the brilliant scarlet of the blossoms, which are borne on stems about 3 feet high. Blooms in midsummer.

MYOSOTIS palustris. Forget-me-not. A low-growing plant, producing sprays of small blue flowers; thrives best in a cool place and blooms in May and June.

OROBUS vernus. A low, spreading plant, with bright, pea-like pink-andwhite flowers in early spring. Very hardy and easily grown.

PANSIES. Large plants, choice strain. $50 \mathrm{cts}$. for I0, \$5 per Ioo.

PAPAVER orientale. Oriental Poppy. The intense scarlet flowers are produced in May and June on stems about 2 feet tall. The base of each petal is marked with a Maltese cross of purple-black; a showy plant; loses its foliage in summer.

Orientale bracteatum. Similar to the preceding, but the flowers are a deeper red.

Involucratum maximum. The deepest crimson of all, sometimes known as Parkman's Poppy. All the above Poppies do best if planted in the autumn.

Nudicaule. The Iceland Poppy. Single flowers in shades of orange, white and yellow. Plants bloom in spring and summer.

PARDANTHUS sinensis. Blackberry Lily. Flowers are bright orange, borne on stems about 3 feet tall in midsummer. The seedpods resemble blackberries.

\section{PEONIES}

Chinese and Japanese

Peonies, the most showy flowers in cultivation, are particularly adapted to our climate. They are much used for masses in cemeteries, parks and pleasure-grounds.

Strong plants, your choice, 35c each, $\$ 3$ for 10 , \$25 per 100 , except Festima maxima.

Divided plants are offered of named varieties, having from one to three eyes. When planted in the fall about 80 per cent bloom the following year.

Mixed varieties, unnamed, to color, large clumps, 15 cts. each
CHINESE AND JAPANESE PEONIES, con.

Buyckii. Pink, salmon center.

Carnea elegans. Light pink, rose petals. Delache. Dark red.

De Villeneuve. Dark pink.

Duc de Cazes. Dark pink, salmon center.

Duchess of Orleans. Rose.

Festiva maxima. White center, petals tinged with carmine. 50 cts. each.

Francis First. Pink.

Illustration. Lively rose.

Indispensable. Soft rose.

Louis Van Houtte. Crimson.

Madame Mechin. Dark red.

Marechal Vaillant. Late; red.

Marquise de la Tourette. Wine-purple.

Mme. Cheney. Late; pink.

Paganini. Lively rose.

Pottsi plena. Dark red.

Prolifica tricolor. White, with yellow.

Reine Potard. Dark pink.

Souvenir d'August Miller. Purple.

Tricolor Grand de Flora. Rose.

\section{P AONIA OFFICINALIS}

These Peonies are very desirable, as they bloom a week or ten days earlier than the preceding sorts.

Price, 25 cts. each, \$2 for 10

Double Red. Double Rose.

Double White, with pink tinge.

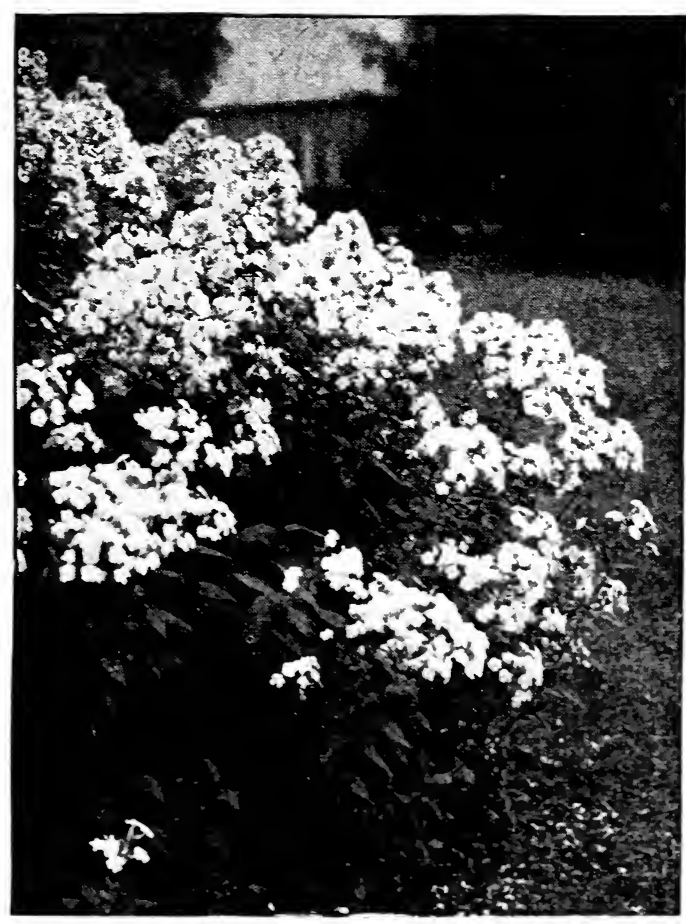

Hardy Perennial Phlox (see page 28) 


\section{HARDY HERBACEOUS PERENNIALS, continued}

PHALARIS arundinacea variegata. Ribbon Grass. Cultivated for the attractive foliage, which is deep green with a longitudinal stripe of white.

\section{PHLOX}

Paniculata, or Decussata

This list includes the best varieties of Hardy Phlox. The flowers range in color from pure white to the deepest purple, and are borne very freely in July and August. We offer the following named varieties:

Charles Darwin. Salmon-pink.

Coquelicot. Bright coral-red.

Cross of Honor. Pink and white.

Eclaireaux. Purplish crimson.

Esperance. Lavender.

Ferdinand Cortez. Bright crimson.

Gen. Chanzy. Scarlet-pink.

Independence. Pure white.

Iris. Purplish blue.

James Bennett. Pink.

James Galloway. Light crimson.

Le Feu de Monde. Salmon-red.

Lumineaux. Large pink, center light.

Michael Buchner. Light pink, dark center.

Mme. Meuret. Bright red.

Mme. P. Langier. Bright red.

Ornament. Large; red.

Pink Beauty.

R. P. Struthers. Crimson, dark center.

Saisons Lierval. White, pink eye.

Wm. Muhle. Large; salmon-pink.

Phlox subulata. Moss Pink. A creeping plant, useful for ground-cover and rockwork. We offer three varieties. Dark Red, Lilac and White.

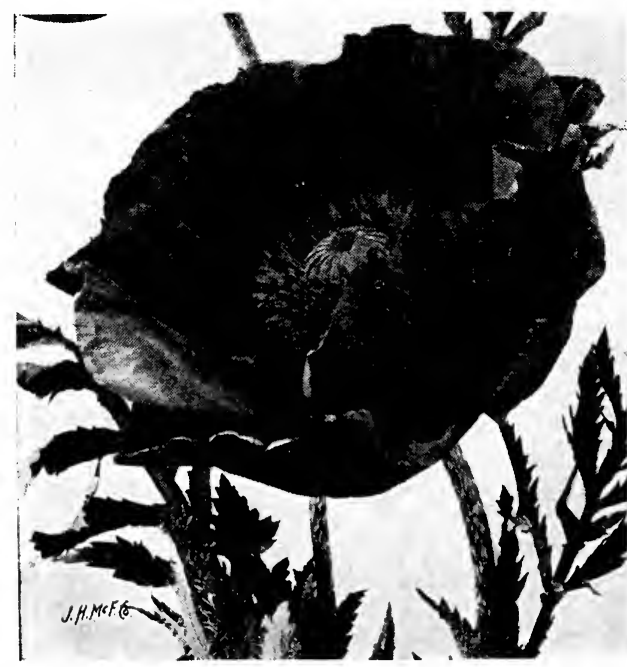

Oriental Poppy (see page 27)
PLATYCODON grandiflora. Chinese Bellflower. The star-shaped blossoms resemble those of the campanula. They are borne on stems 2 feet high, and are produced very freely during the summer. We offer two colorsBlue and White.

Grandiflora Mariesii. Similar to the preceding, but dwarf and has larger flowers; colors deep blue or lavender.

POLYGONATUM multiflorum. Solomon's Seal. These plants will grow in shaded, moist places as well as in the ordinary bed. They are 3 feet in height; the flowers are white, with a greenish tinge.

POLYGONUM cuspidatum. A perennial buckwheat, very hardy and robust, attaining a height of 8 feet or more, covered with quantities of small white flowers in summer. It spreads rapidly by underground stems.

PRIMULA POLYANTHA. Primrose.

Flowers bright yellow or maroon and yellow, on stems 6 to 12 inches tall, in clusters of a dozen or more.

PYRETHRUM, Hybrid Sorts. A good collection of single varieties. 25 cts. each, \$2 for Io.

Uliginosum. Giant Daisy. Flowers like great white Daisies and borne freely in late summer; 3 to $5 \mathrm{ft}$. high.

RUDBECKIA laciniata $\boldsymbol{f}$. pl. Golden Glow. A well-known plant, growing from 6 to Io feet tall and producing an immense number of brilliant yellow flowers; grows rapidly and makes a splendid appearance.

Speciosa. Flowers bright yellow, with a brownish purple central disc; 2 to 3 feet high.

SABBATIA chloroides. This beautiful plant is now largely planted on the borders of brooks, lakes and in moist meadows. It will also do well in gardens. It is one of the most charming of our native flowers, blooming in summer, with soft, rose, very lovely flowers. $\$ 6$ per Ioo.

SOLIDAGO. The well-known Goldenrod. Collected plants of good varieties only. Offered in mixture.

SPIRAA Aruncus. Goat's Beard. Plants from 3 to 5 feet high, with feathery spikes of white flowers in June and July.

Filipendula. Foliage finely cut and in broad rosettes. Flowers single, white, borne freely in early summer.

Filipendula fl. pl. Similar to the above, with double, white flowers, which are more enduring. 


\section{HARDY HERBACEOUS PERENNIALS, continued}

Spiræa palmata. Flowers pale pink; blooms in July; plants 2 to 3 feet tall; charming.

Palmata elegans. A superior variety, with white flowers and red anthers; grows taller.

Ulmaria. English Meadow Sweet. The double, white flowers are borne on stems from I to 3 feet high and produced freely during summer. $25 \mathrm{cts}$. each, \$2 for Io.

Ulmaria variegata picta. Similar to the preceding but with variegated foliage. 25 cts. each, $\$ 2$ for Io.

VERNONIA Noveboracensis. Ironweed. Flowers deep purple, borne on tall stems in late summer. Excellent for damp places as well as borders.

VIOLA palmata cucullata. The common blue Violet. Flowers Blue, White or Variegated. Separate colors.

Odorata. The familiar sweet Violet. Flowers are blue or white and very sweet; in early spring.

Schonbrunn. This came originally from the Emperor of Austria's garden, whence the name. It begins to flower
Viola Schonbrunn, continued in this latitude in October, and continues until severe weather, even opening in January and February, if there are a few warm days. The most abundant flowers come in April. Flowers are small, blue and very fragrant.

Pedata. Flowers light violet, rarely white, with a delicate fragrance. Collected plants.

YUCCA filamentosa. Adam's Needle. Sometimes considered a shrub. Good for grouping in hardy garden border or for rockwork. Creamy white flowers and long, lance-like foliage, with threads breaking out from the edges. 35 cts. each, $\$ 3$ for IO; 4 yrs. 25 cts. each, $\$ 2.25$ for 10 .

\section{TENDER BULBS}

To be kept in the cellar in winter like dahlias GLADIOLUS.

Scarlet, mir

Scarlet, mixed.......... So $25 \quad \$ 200$

Pink, mixed.......... $35 \quad 250$

White, mixed.................... $35 \quad 250$

Striped, mixed........ $40 \quad 300$

Yellow, mixed........ $75 \quad 500$

\section{FRUIT DEPARTMENT}

\section{APPLES}

All Apples, 5 to 7 ft., $\frac{11}{16}-$ inch caliper, 50 cts. each, $\$ 4$ for 10

\section{SUMMER}

Early Harvest. Medium size, pale yellow; tender, subacid. Among earliest to ripen. Tree vigorous and good bearer. Good cooking Apple.

Red Astrachan. Fruit medium size, bright red; acid and juicy, fine for cooking. Tree hardy, rapid grower; bears well in July and August.

Sweet Bough. Big, pale yellow with faint blush; sweet, crisp and juicy. Tree fair grower; bears freely in August.

Tetofsky. Medium size; yellow streaked with red; early bearer. Tree grows upright and vigorous.

Yellow Transparent. Medium size, roundish; pale yellow, of good quality, tender and juicy. Tree dwarf; young and heavy bearer. Ripens in August.

\section{FALL}

Gravenstein. Extra-large, perfectly formed Apple; orange-yellow, striped with red; flesh tender and juicy. Tree hardy, erect and very productive. A great favorite.

\section{FALL APPLES, continued}

Maiden Blush. A large, flat, lemonyellow Apple, with crimson blush; flesh very white, not highly flavored but pleasant. Extensively used for drying.

Red Siberian Crab. A small Apple used only for cooking, making good jelly or preserves. Very hardy and ornamental.

Yellow Siberian Crab. A better bearer than the above, which it greatly resembles, but is yellow.

\section{WINTER}

Baldwin. A great favorite in New England. A large, bright red Apple, with firm and thick skin, making a splendid shipper. Good flavor. Tree strong and very productive when mature. December to March.

Fameuse. Medium size; deep red on white; flavor excellent, good for home use and sells well in local markets. A splendid dessert apple, but not particularly good for cooking. Tree a vigorous, upright grower. Not a good shipper. October to midwinter.

Hubbardston Nonsuch. Large, round; solid; pale red; mild, juicy and pleasant. Grows freely; very productive. November to January. 


\section{WINTER APPLES, continued}

King. (Tompkins County.) Very large and beautiful red; of fine quality. Flesh subacid, crisp and juicy. If the tree were a better grower and not so subject to breakage this would be one of the very best. Only good for certain sections, where it is a good moneymaker.

McIntosh Red. Medium size; skin bright red; flesh white, slightly tinted with pink, mellow, delicious and perfumed. A good keeper. Tree vigorous, spreading grower, long-lived and productive. November to February. It belongs to the Fameuse family.

Northern Spy. Large, pinkish-red Apple tinged with carmine. Flesh rich, refreshing and aromatic. Tree rugged and sturdy, rapid, erect grower and free producer. Varies somewhat in different soils. January to May.

Porter. Long in cultivation and a great favorite. Fruit acid, but excellent for eating when ripe; always good for cooking. Tree irregular in growth, but a good bearer.

Rhode Island Greening. Widely planted and valuable in the East; one of the best cooking Apples. A large, round greenish yellow Apple. Tree somewhat ungainly, free grower, great bearer, December to February.

Russet, Golden. Medium size; bright reddish russet. Crisp and high-flavored, a good dessert Apple. Tree hardy and bears well. November to April.

Russet, Roxbury. Good size; greenish russet. Flesh juicy and pleasant. Tree grows freely and bears finely. The latest-keeping Apple. January to June.

Talman Sweet. Medium size; pale yellow tinged with red; flesh rich, sweet and solid. Tree grows well, is erect and a generous bearer. November to April.

Wealthy. Medium-sized red Apple; flesh is tender, crisp, juicy, fine-grained and aromatic. Tree vigorous, bearing young and bountifully. November and December.

Yellow Bellflower. Large; yellow touched with red. Flesh crisp and juicy. Tree hardy and long lived. December to January.

York Imperial. A good Apple, mellowing for use soon after picking and if properly stored can be kept until new crop comes. Medium size; greenish yellow, tinged with crimson; of extrahigh flavor, firm, tender and juicy. Tree early and abundant producer; growth upright, slightly spreading, and quite dense, vigorous and healthy. November to February.

\section{PEARS}

All Pears, except Beurre Bosc, 5 to $6 \mathrm{ft}$., 50 cts. each, $\$ 4$ for 10

\section{SUMMER}

Bartlett. Large; gold-colored, with crimson blush; thick skinned, buttery, mellow, excellent for eating early in season, yet if picked right and stored properly keeps well. Most highly esteemed for packing and shipping. Tree a vigorous, erect grower and great bearer. Sept.

Clapp's Favorite. Fine-appearing; lemon yellow with a bright blush; flesh of fine texture, juicy and melting. Tree sturdy and vigorous. Middle of August.

Flemish Beauty. A particularly elegant, large fruit; pale yellow, almost entirely russeted with reddish brown when ripe; of fine, delicate, sweet, rich taste. Tree hardy, but needs sun. September.

Giffard. One of the best early summer Pears. Yellow with red cheek. Should be ripened in the house.

Osband's Summer. Yellow with red cheek; medium size; mild and pleasant.

\section{AUTUMN}

Beurre Bosc. Handsome and big, deep yellow, russeted Pear of highest quality and rich flavor. Tree fair grower and bears well. September and October. 75 cts. each.

Duchesse d'Angouleme. Large, fruit frequently weighing a pound; greenish yellow slightly russeted. Flesh white, juicy and delicious. Trees bear young. October.

Louis Bonne de Jersey. A late summer or early autumn Pear, of medium size and fine flavor. The skin is rough and it should always be peeled before eating.

Seckel. Small; yellowish brown; of fine flavor, rich, spicy and sweet. Splendid for eating, cooking and market. Tree small but erect. September and October.

Sheldon. Medium to large; yellow and carmine; flesh melting, sweet and juicy. Tree healthy, hardy and productive. October.

\section{WINTER}

Beurre d'Anjou. Large; light green with russet red cheek; flesh excellent; snappy, vinous flavor. Tree grows and produces strongly. November and December.

Lawrence. Medium; greenish yellow, russet-marked; fruit of melting, pleasant, sweet flavor. Tree grows moderately, bears freely, lives long. December and January. 


\section{PEACHES}

All Peach trees, 4 to $5 \mathrm{ft}$., 25 cts. each, $\$ 2$ for 10

Belle of Georgia. A very profitable tree, whose great merit is its ability to bear. Fruit very large; greenish white, with red cheek; flesh white and firm. Tree vigorous and hardy, and bears grandly.

Carman. Large; yellowish white; fruit tender, creamy white tinged with red, of vinous flavor. Tree free from rot; very hardy; the north China type, productive every year.

Chair's Choice. Large; deep yellow, with red cheek; flesh firm and yellow. Ripening in October.

$\checkmark$ Champion. A splendid variety for any and all regions. Very large; creamwhite with red blush. Flesh sweet and juicy, very high quality. Tree of extreme hardiness and produces freely.

Crawford's Early. Large; deep yellow with slight blush; luscious, sweet yellow flesh. An old standby. Tree strong and productive.

Crawford's Late. A standard late Peach. Superb in color and form. Large, yellow, with flesh of fine quality and exquisite taste. Trees produce heavily.

Crosby. Medium; bright yellow with crimson splashes; flesh yellow, changing to red at stone, firm, fairly juicy and of good quality. Tree hardy and productive.

Elberta. Large; yellow, reddish tinge; flesh quite juicy, of high quality. Tree vigorous and sturdy; thrives in widely different localities.

Foster. Exceptionally large, yellow, beautiful, rich, juicy peach. Trees quite prolific and uniform in size.

Mayflower. Earliest Peach known for the North. Fruit medium; red all over, firm and pleasant. Tree strong, thrifty, abundant bearer.

Mountain Rose. Large and round; white, covered with dark red; flesh white, stained red at stone, juicy, delicious and sweet. Tree hardy and productive.

Oldmixon Free. Large; pale yellow with red cheek; flesh white, red stain at stone, tender and excellent. Tree large, does well in many localities.

Stump the World. One of the standard Peaches. Large; red and white; flesh juicy, of finest flavor. Tree vigorous, producing big crops.

Waddell. North China type. Medium to large; yellow; flesh firm and sweet, keeps well. Tree very hardy, bears good crops.

\section{CHERRIES}

All Cherry trees, 5 to $7 \mathrm{ft}$., 50 cts. each, $\$ 4.50$ for 10

Black Tartarian. The best of the sweet Cherries. Fruit heart-shaped, bluish black, juicy and sweet, and on account of its delicious flavor very fine for home table. Tree is erect, a compact grower, exceedingly hardy and a regular producer of immense crops.

Early Richmond. A standard variety, popular and well known. Medium size, dark red, juicy, rich and acid. Tree is hardy and vigorous. One of the best cooking Cherries.

Governor Wood. Medium; heart-shaped; light yellow, marked light red; juicy, sweet and rich. Tree healthy, produces freely.

May Duke. A large, dark red, subacid Cherry, very dependable and adaptable. Fruit matures slowly, but is of excellent quality. Tree strong, bears well.

Napoleon. (Bigarreau.) Very large; attractive, reddish yellow; delicious and sweet. Excellent shipper and famous canner. Tree hardy and enormous bearer.

Schmidt's. (Bigarreau.) Large; deep color; of good flavor and bears abundantly.

Windsor. Large; dull red, almost black. Sweet, remarkably firm and meaty. Tree noted for hardiness. Great favorite in the East.

Yellow Spanish. Extra large, heartshaped; pale yellow with blush on sunexposed side.

\section{PLUMS}

All Plum trees, 5 to $7 \mathrm{ft}$, 50 cts. each, $\$ 4.50$ for 10

Bradshaw. Large; bluish purple; a little acid but juicy and good.

Coe's Golden Drop. Large; light yellow, rich and sweet.

German Prune. Very large; black or deep blue with dense bloom, juicy and luscious. Just right for preserving.

Tree strong, bears freely.

Green Gage. A small, delicious, greenish yellow plum. Tree grows well, produces good crops.

Lombard. Medium-size; egg-shaped; violet-red; juicy and agreeable, of splendid quality. Tree unusually vigorous. Very prolific, well adapted to light soils.

Yellow Egg. Large; light yellow; eggshaped; handsome and of fair quality. Tree hardy and productive. 


\section{JAPANESE PLUMS}

Abundance. Large; amber turning to bright cherry; flesh juicy, tender and sweet. Tree produces very freely.

Burbank. Large, round; cherry-red; very sweet with distinctive pleasant flavor. Tree grows vigorously and bears finely.

Chabot. A strong grower and productive; fruit oblong, yellow and of excellent quality.

Red June. Extra large; copper red. Fruit sweet and well-flavored. Tree healthy and sturdy, produces sure and dependable crop. The earliest of this group.

Satsuma. Large; purplish crimson; of excellent quality, with exceedingly small pit. Tree valuable and productive.

Wickson. Very large, oblong-pointed; glowing carmine with heavy white bloom. Keeps well and is a good shipper. Tree upright in growth.

\section{QUINCES}

Both Quince trees, 3 to $4 \mathrm{ft} ., 40$ cts. each, $\$ 3.50$ for 10

Champion. Fruit large and oval, quality excellent, tender and crisp. Especially good for preserving. Tree vigorous and prolific.

Orange. Large; golden yellow; quite tender after cooking, and of good flavor. Bush strong, bears young and yields immense crops.

\section{GRAPES}

All Grapes, two-year vines, 20 cts. each, $\$ 1.50$ for $10, \$ 10$ per 100

Agawam. Dark red; bunches large and loose; berries juicy, sweet, meaty and aromatic. Vine large grower, fairly hardy and productive.

Brighton. Large; copper-red; clusters big and loose; berries very perfectly formed, sweet and of the best flavor. Vine thrifty and productive; should be planted with other sorts.

Concord. Black; bunches close and large; berries tender, juicy and sweet. Vine very hardy, productive. Probably the best-known Grape. Ships well and sells well.

Delaware. Small, light red; cluster compact; berries small, sugary, very delicious. Vine hardy and produces splendidly; foliage clean. Requires rich soil and care.

Moore's Early. Large; black; bunches medium, firmly held together; flesh pulpy, flavor good, quality medium or better. Vine healthy, hardy and thrives in moist soil.

\section{GRAPES, continued}

Niagara. An exceptionally fine, greenish white Grape, with large, compact bunches and exquisitely flavored, melting, sweet, large, tender berries. Vine vigorous, hardy and productive. Succeeds almost everywhere.

Perkins. An early, almost white Grape of great hardiness and fairly productive. Flavor similar to the wild Grape.

Salem. Copper-red; cluster big and dense; fruits large, juicy, tender and sweet, of fine quality. Vine healthy, bears well in good seasons.

Wilder. Black. Bunches large; berries round and big; flesh tender, juicy and sweet. Vine vigorous and prolific.

Worden. Large; handsome, shining black. Bunches good size; berries large, sweet and lively flavor. Vine thrifty, vigorous and exceptionally hardy.

\section{BLACKBERRIES}

All Blackberries, 75 cts. for $10, \$ 5$ per 100

Kittatinny. Fruit large, rich and glossy Bush hardy and productive.

Lucretia. (Dewberry.) A trailing form of Blackberry. Fruit superb, of good size, jet-black, rich and melting. Bears in great profusion. Thrives well everywhere. Especially valuable for market, as it ripens between the raspberry and Blackberry.

Snyder. Medium size; sweet and juicy to core; very hardy and productive. Ships well.

Blowers. Most sturdy Blackberry. Extra large; jet black; exceedingly sweet. Vines very productive, and fruit a good shipper.

Rathbun. Native of New York. Ripens early. Very large fruit, which is jetblack, of good quality, juicy, sweet and luscious. Strong grower; very hardy.

\section{CURRANTS}

\section{All Currants, $\$ 1$ for $10, \$ 8$ per 100}

Black Naples. The best black Currant. Sturdy grower and very productive.

Cherry. Extra large; dark red; bunches short. Plant vigorous and productive.

Fay's Prolific. Large; red; long bunches. Productive. Fruit of fine quality.

White Grape. Large; yellowish white; excellent quality, quite mild acid; good table variety. Bears well.

\section{GOOSEBERRIES}

Downing. Medium-sized, light green berries of pleasant flavor, soft and juicy. Plant vigorous and prolific. Good for table and market. 2-yr. plants $20 \mathrm{cts}$. each, \$I.5o for ro. 


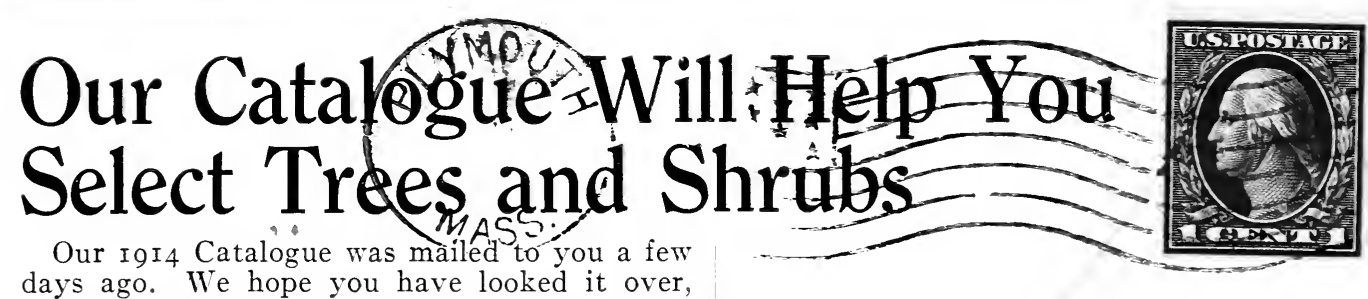
and selected the trees and shrubs that you intend to plant this spring.

Trees from our Nurseries are not like most trees. We dig them fresh for your order-no piling up to dry out, which means a tree halfdead when delivered. Our soil is sandy loam, which makes many fibrous roots to feed the tree when transplanted; our methods of packing insure safety in shipping and arrival in the best condition for planting.

We shall be glad to give further information about our trees and plants, or to help you in planning your grounds for the best effects. Write us or, better still, visit our Nurseries. It will be a pleasure to assist you to have an unusual planting at your home.

OLD COLONY NURSERIES Inc.

Plymouth, Massachusetts

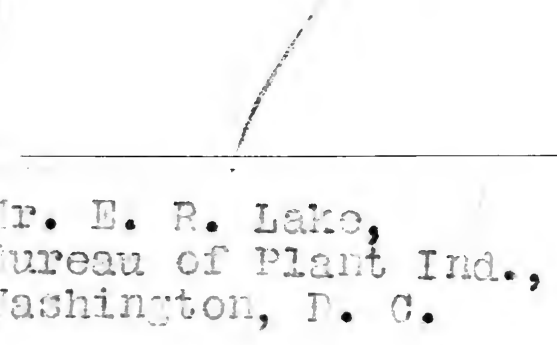

\section{Old-Fashioned Perennials For All-Summer Blooms}

A garden without perennials is like a gallery without pictures-dull and uninteresting, and no one cares to visit it.

Phloxes among the shrubs, Peonies in mass or bordering the walks, Columbines in clumps of a dozen or more, -all make the garden a place in which you want to spend the day. Border plants like Arabis with its white flowers, Sweet William in gay blooms, and the Evergreen Thrift (Armeria maritima), are needed in every planting.

We have them all, and many more. The list is given on pages 22 to 29 of the Catalogue. Write us about your garden, and let us suggest the plants that are best suited to your location.

\section{Our Catalogue Will be Mailed Free to Anyone Who Asks for It}

If you have a friend who expects to plant trees or shrubs this spring, send us his name and address. We will send a copy by first mail.

\section{OLD COLONY NURSERIES Inc. PLYMOUTH, MASS.}

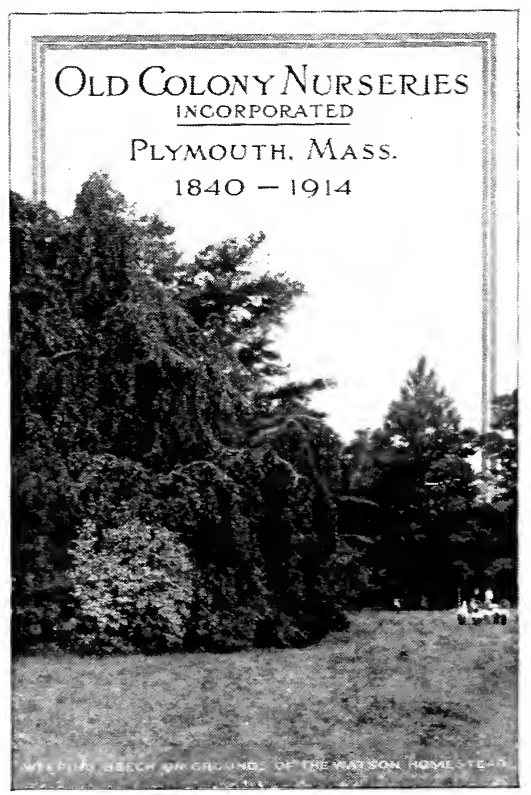




\section{Plant Trees and Shrubs for a Definite Purpose}

Your home grounds will have a far more pleasing appearance if you have a definite plan for the planting, and a reason for using the various trees or shrubs. Too many places are planted on the "hitor-miss" plan-and it usually is a "miss."

If the house or other buildings are exposed to strong winds, plant a windbreak of Norway Spruce. The view of the garage, barn or unpleasant surroundings can be cut off by a screen of Lombardy Poplars. If lower screens are desired, use Bush Honeysuckle, Philadelphus, Ninebark or some of the Viburnums.

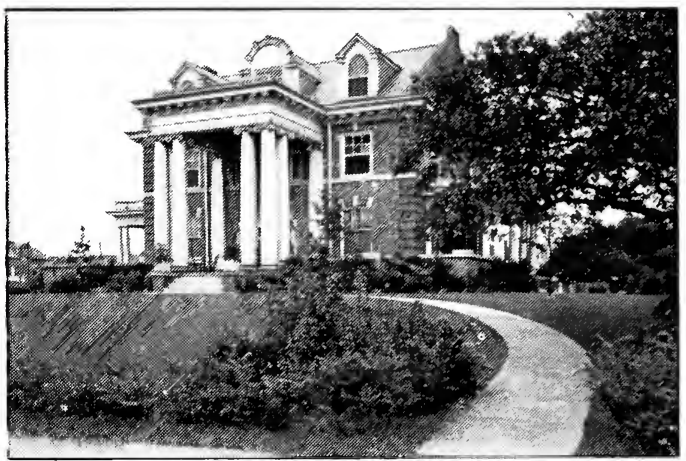

A hedge is preferable in every case to a fence, and can be made an equally effective barrier. For a street or division hedge the Barberry is desirable; if a tall hedge is needed, use the Privets or the Buckthorn. The American Arborvitæ is almost indispensable as a hedge plant. Flowering hedges are always beautiful; Deutzias in variety, Forsythias (the earliest shrubs to bloom); Spireas (either Van Houttei or Anthony Waterer), are among the best of the ornamental hedges. Evergreens and hedges always give an air of refinement and seclusion to the home surroundings.

For covering the veranda or pergola we suggest the Rambler Roses, Clematis Jackmanii or Henryi, or both in combination, or Hall's Honeysuckle, which, by the way, was introduced by Mr. B. M. Watson. The street trees should be Norway Maples, Elms, Lindens or Oriental Plane; but the specimens for the lawn should include the uncommon trees, like the European Beeches, Tulip Trees, Tartarian Maples (whose foliage is brilliant crimson in autumn), and the Purple-leaved Plum. Other trees may be selected to suit special locations.

Specimen evergreens must also be included,

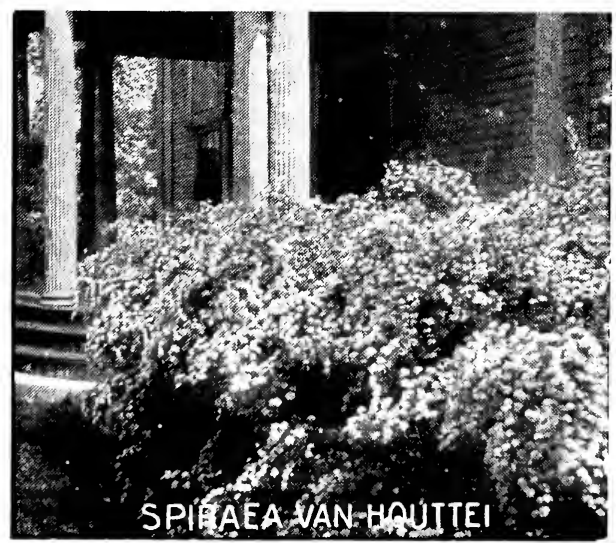
and our selection would be Hemlock, White or Silver Fir, Norway and Koster's Blue Spruce, the Japanese Yew, Irish Juniper, and with the evergreens be sure to include the Rhododendrons and Kalmia.

We shall be glad to help you to select the trees and shrubs adapted to your special conditions. The small order receives just as careful attention as the large one. Write us about your place, giving some details as to location, whether level or hilly, with a word about the soil. We can help you.

\section{OLD COLONY NURSERIES Inc. Plymouth, Mass.}


Make remittances by Post Office Money Order, Express Money Order, Bank Draft or Registered Letter. Personal checks will also be received. Do not send postage stamps instead of money. Make all money orders, drafts and checks payable to Old Colony Nurseries, Inc.

\section{ORDER SHEET \\ OLD COLONY NURSERIES, Inc.}

Successors to T. R. WATSON

PLYMOUTH, MASS.

Name

Street and No.

Post Office

County

State.

$R . R$. or Express Station

Send by

Preight or Express, say which

Ship on or about

Amount Enclosed

Please state whether in stamps, money order, check or draft

Always write your Name, Post Office, County and State very plainly. By so doing you avoid the possibility of delay and mistakes in filling your orders. Carry out prices.

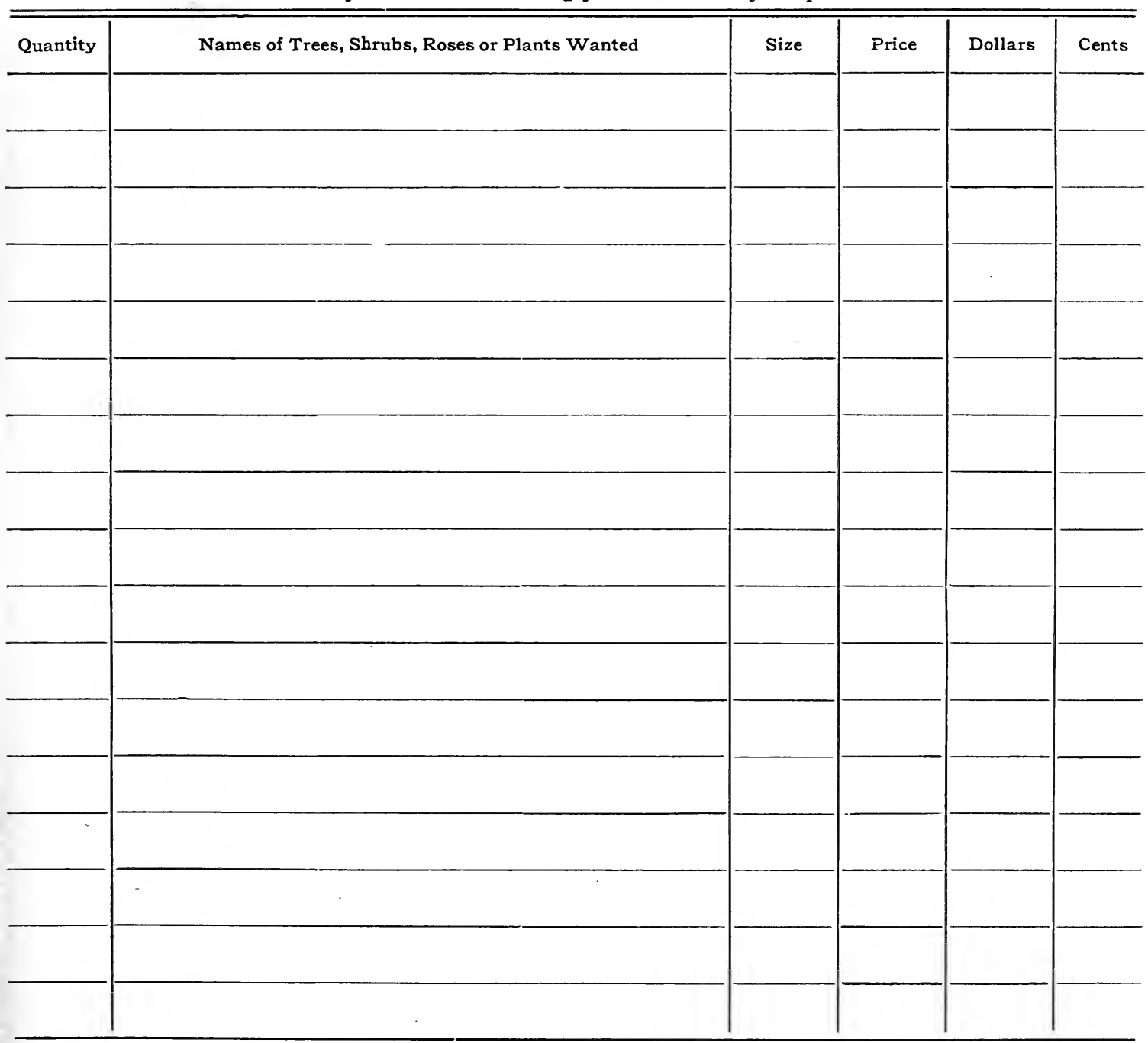



GOOSEBERRIES, continued

Red Jacket. An English variety. Large; dark red, transparent, fine quality. Grows with vigor and does not mildew. Plants 25 cts. each. \$I.75 for Io.

Windham Industry. Another English variety. Large; dark red, good flavor. Plant very strong and produces well. Plants 25 cts. each, $\$$ I. 75 for Io.

\section{RASPBERRIES}

75 cts. for $10, \$ 5$ per 100 , except as noted

Kansas. (Black Cap.) One of the best thimble berries. Hardy and productive, with extra-large fruit.

Cuthbert. Fairly large; of a deep, luxuriant crimson, very hardy, sweet and of high quality. Plants perfectly vigorous, grow strongly and bear fine crops.

Miller's. Bright red, firm berries; bush hardy and big producer. Ships well and brings good prices.

St. Regis. Large, red, attractive berries. The canes are of strong growth, absolutely hardy and succeed upon all soils. This variety is peculiar in that it gives a crop of fruit the first year planted, and in following years two crops. SI for IO, \$8 per Ioo.

Golden Queen. A clear amber-yellow; well formed and of high quality. The best and hardiest yellow or white Raspberry.

\section{RHUBARB}

Linnæus. (Myatt's.) Probably the best variety cultivated. Stalks long and heavy, not stringy or tough; flaver subacid, very pleasing. I 5 cts. each, Si.to for IO.
ASPARAGUS

Three-year roots, $\$ 1.50$ per $100, \$ 10$ per 1,000

Conover's Colossal. Exceptionally fine; white, remarkably tender and highflavored; superior in size. Often cut in the second year.

Giant Argenteuil An early variety, which produces large crops that always bring the best prices in market. Stalks are large, very white; plants long-lived.

\section{STRAWBERRIES}

\section{All Strawberry plants, $\$ 1$ per 100}

$\mathbf{S}$ indicates staminate or self-fertilizing varieties.

Bubach. This standard old variety is a veritable gold-mine. Berries large, thick, meaty, fine-grained, heary and of rich color. Plants thrive in any soil or section.

Excelsior. S. Large, firm, finely colored and of good shape. Plants large and strong, produce immense crops. The standard for earliness.

Marshall. S. An old, well-known variety. Berries of large size and exquisitely rich flavor and fancy quality. Always brings top-notch prices. $\$ 6$ per I, ooo.

Nick Ohmer. S. A berry which makes a fine show in market and brings fancy. prices. Large, firm, delicious, globeshaped fruit, glossy red with high colcr all the way through.

Splendid. Good in every way. Grows strongly and should be thinned for best results. Bears fine crops of uniform. medium-sized fruit.

Minuteman. Late berry; productive ard cf good quality.

\begin{tabular}{|c|c|c|c|}
\hline PAGE & FAGE & PAGE & PAGE \\
\hline Alder. . & Choke Berry .... & Larch & $\ldots . .19-2 I$ \\
\hline Alder, Black. & Coffee Tree..... & Laurei. & Snowberry ....... I5 \\
\hline Allspice, Carolina ... I I & Cypress....... & Leucothoe........ 4 & Snowdrop........ I 5 \\
\hline Almond.. $\ldots \quad \ldots 9$ & Desmodium........ I I & Lilacs.......... I3. I4 & Sorrel.......... I5 \\
\hline Althea.......... 9 & Deutzia......... I & Linden $\ldots . \ldots \ldots 7$ & Spice Bush........ I5 \\
\hline Andromeda.......4, 9 & Dogwood....... I I, I 2 & Magnolia ... & Spiræa, Blue ...... I I \\
\hline Angelica Tree...... 9 & Elder............ 2 & Maidenhair Tree... 7 & Spiræa.......... \\
\hline Apples, Flowering... 9 & $\mathrm{Elm} \ldots \ldots \ldots 6$ & Maple ........ & Spruce........ 3 \\
\hline Arborvitæ........ 2 & Euonymous ...... 4 , I2 & Mock O ange........ I6 & St. John's IIort.... I5 \\
\hline Ash $\ldots \ldots \ldots \ldots \ldots 7$ & Fir............ & New Jersey Tea.... . I4 & Styrax......... I5 \\
\hline Asparagus.........33 & Fringe Tree ........ I 2 & Ninebark Tree...... I 4 & Sumach......... \\
\hline Azalea............ Io & Fruit Departinent... & Oak............ 8 & Sweet Gum... \\
\hline Barberry ........... Io & $29-33$ & Oleaster. & Sweet Pepper Bush. . I6 \\
\hline Bearberry........ 4 & Globe Flower, Japan I3 & Oriental Plan ...... 8 & Syringa .......... I 6 \\
\hline Beech... & Golden Bell......... I 2 & Pea Bush. & Tamarisk.......... I6 \\
\hline Birch.......... $5 \ldots$ & Golden Chain....... 6 & Pearl Bush......... I4 & Tulip Tree......... 8 \\
\hline Blueberry . . . . . . . . I I & Groundsel 1 ree...... I 2 & Perennia!s. . . . . 22-29 & Tarnish Tree....... 8 \\
\hline Broom, Scotch...... I4 & Hemlock........... & Plum Flowering 8 & lines............. \\
\hline Buckthorn .......... II & Honeysuckle....... I 2 & Poplar........... 8 & Walnut.......... \\
\hline Butternut....... 5 & Hornbeam.........6 6 & $\ldots \ldots \ldots$ I4 & Weigela.......... \\
\hline Calico Bush......... I I & Horse-Chestnut..... & Purple Fringe........ I6 & Willow \\
\hline Catalpa......... 5 & Hydrangea........ If & $\ldots \ldots \mathrm{I}_{4}$ & IVitch-Hazel........ I \\
\hline Cercidiphyllum..... 5 & Judas Tree........ 6 & Red Bud ........ 6 & Yellow Root........ I 7 \\
\hline Cherry.......... 6 & Juneberry. . . . . . . 6 & Retinospora....... 3 & Yellow-VIood....... 8 \\
\hline Chestnut......... 5 & Juniper $\ldots \ldots \ldots \ldots 2$ & Rhododend.ons.... 4 & Yew, Japanese..... 3 \\
\hline
\end{tabular}

The McFarland Publicity Service, Harrisburg, $\mathrm{Pa}$. 


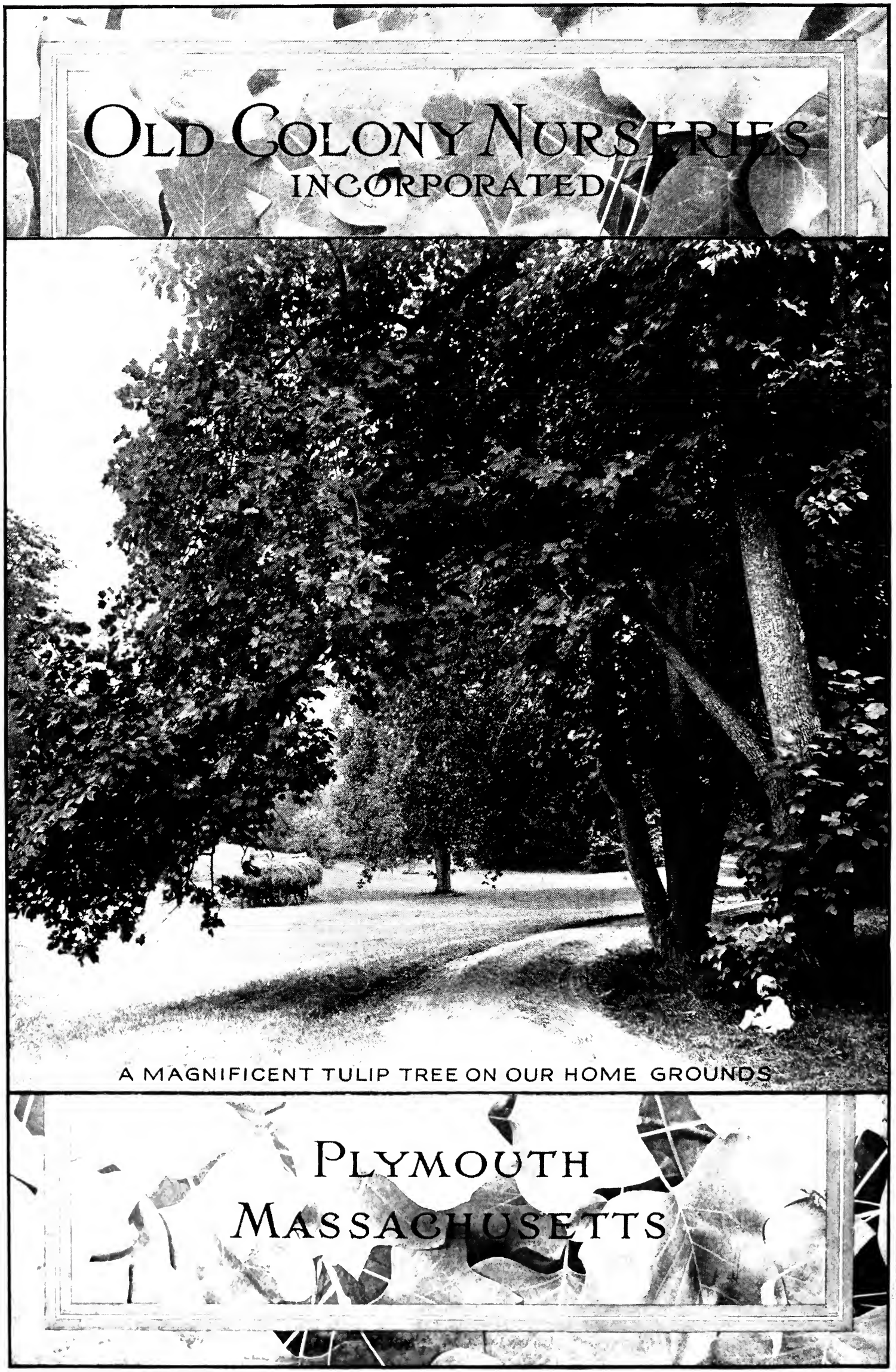

